\author{
UNIVERSIDADE DE SÃO PAULO \\ FFCLRP - DEPARTAMENTO DE QUÍMICA \\ PROGRAMA DE PÓS-GRADUAÇÃO EM QUÍMICA
}

\title{
Análise voltamétrica de 3,4-metilenodioximetanfetamina
}

\author{
TÚLIO DE CASTRO AGOSTINHO
}

Dissertação apresentada à Faculdade de Filosofia, Ciências e Letras de Ribeirão Preto da USP, como parte das exigências para a obtenção do título de Mestre em Ciências, Área: Química.

RIBEIRÃO PRETO - SP 


\author{
UNIVERSIDADE DE SÃO PAULO \\ FFCLRP - DEPARTAMENTO DE QUÍMICA \\ PROGRAMA DE PÓS-GRADUAÇÃO EM QUÍMICA
}

\title{
Análise voltamétrica de 3,4-metilenodioximetanfetamina
}

\author{
TÚLIO DE CASTRO AGOSTINHO
}

Dissertação apresentada à Faculdade de Filosofia, Ciências e Letras de Ribeirão Preto da USP, como parte das exigências para a obtenção do título de Mestre em Ciências, Área: Química.

Orientador: Marcelo Firmino de Oliveira

RIBEIRÃO PRETO - SP

2012 
Autorizo a reprodução e divulgação total ou parcial deste trabalho, por qualquer meio convencional ou eletrônico, para fins de estudo e pesquisa, desde que citada a fonte.

FICHA CATALOGRÁFICA

Agostinho, Túlio de Castro

Análise voltamétrica de 3,4-metilenodioximetanfetamina. Ribeirão Preto, 2012.

66 p.: il. ; $30 \mathrm{~cm}$

Dissertação de Mestrado, apresentada à Faculdade de Filosofia, Ciências e Letras de Ribeirão Preto/USP. Área de concentração: Química Analítica

1. Química Forense. 2. Ecstasy. 3. Voltametria. 4. Eletroquímica 
AGOSTINHO, T. C. Análise voltamétrica de 3,4-metilenodioximetanfetamina. Dissertação apresentada à Faculdade de Filosofia, Ciências e Letras de Ribeirão Preto da Universidade de São Paulo, como parte das exigências para a obtenção do título de Mestre em Ciências. Área: Química.

Aprovado em:

\section{Banca Examinadora}

Prof. Dr.

Instituição:

Julgamento:

Assinatura:

Prof. Dr.

Instituição:

Julgamento:

Assinatura:

Prof. Dr.

Instituição:

Julgamento:

Assinatura: 


\section{DEDICATÓRIA}

Dedico este trabalho à minha família que sempre me incentivou e ofereceu condições para que eu pudesse seguir atrás de meus sonhos.

À sociedade brasileira por ter custeado todos esses anos de estudo na forma de impostos, pagos por cada cidadão. 


\section{AGRADECIMENTOS}

Agradeço inicialmente aos meus pais Nivaldo e Rosália por terem me dado educação, ensinamentos e terem moldado a pessoa que sou hoje, além de terem me proporcionado as condições adequadas para que pudesse chegar até aqui, a eles serei eternamente grato.

Aos meus irmãos Douglas e Maila, meus tios, primos, avós e todos mais das famílias Castro e Agostinho.

À minha namorada Daniele por todo o amor, companheirismo, amizade, momentos felizes e todo o resto que ao seu lado foram todos muito proveitosos e pretendo que continuem existindo!

A todos os amigos que fiz desde a infância, por toda a amizade e o convívio, os quais se eu fosse citar todos os nomes não caberia nesta dissertação e também não conseguiria lembrar todos os nomes! Aos amigos da República Kremutcho (moradores, ex-moradores e agregados), da extinta República All-in (idem!), da minha turma do curso de graduação ( $43^{\mathrm{a}}$ turma de Bacharelado em Química da USP-RP), os veteranos e calouros. Ao Renan, Tomate, Henrique, Eduardo, Emeron e todos os outros da Lagoinha e companhia. Ao Paulo e os outros amigos de São Joaquim da Barra. Ao meu primo Serginho e os amigos de Araraquara e Américo Brasiliense e a todos os outros que porventura posso ter esquecido de mencionar (me desculpem!).

Ao professor Marcelo Firmino de Oliveira, pela orientação desde os estágios durante a graduação até o mestrado, por toda a amizade, respeito e conhecimentos transmitidos, que certamente serão muito bem aproveitados pelo resto de minha vida.

Aos companheiros (e amigos!) de laboratório que muito me auxiliaram durante os anos que por lá estive, pela convivência agradável, pelos momentos divertidos e a ajuda em todos os problemas que surgiram nesta trajetória.

Ao professor Beto, à Jac e ao restante dos seus alunos do laboratório que muito me auxiliaram em uma importante etapa do desenvolvimento deste trabalho. 
Aos professores Celso e Zéfer pelas cartas de indicação para ingressar no programa de pós-graduação, bem como pela amizade e por toda a ajuda prestada quando necessitei.

A todos os professores que tive em minha vida, desde os professores da escolinha infantil, passando pelos professores de futebol, professores do ensino fundamental, ensino médio até os professores da Universidade de São Paulo, por todo o conhecimento e educação transmitidos, pelo respeito, paciência e amizade.

Aos funcionários da Universidade de São Paulo pelos serviços prestados, essenciais para o bom funcionamento da mesma.

À Universidade de São Paulo por propiciar um ambiente agradável para que eu pudesse estudar, aprender e pesquisar, tornando possível a existência deste trabalho.

Às agências de fomento CAPES e FAPESP pelo apoio. 
Here Comes The Sun

Here comes the sun

Here comes the sun

And I say

It's all right

Little darling

It's been a long cold lonely winter

Little darling

It feels like years since it's been here

Here comes the sun

Here comes the sun

And I say

It's all right

Little darling

The smiles returning to the faces

Little darling

It seems like years since it's been here

Here comes the sun

Here comes the sun

And I say

It's all right

Sun, sun, sun, here it comes...

Sun, sun, sun, here it comes...

Sun, sun, sun, here it comes...

Sun, sun, sun, here it comes...

Sun, sun, sun, here it comes...

Little darling

I feel that ice is slowly melting

Little darling

It seems like years since it's been clear

Here comes the sun

Here comes the sun

And I say

It's all right

Here comes the sun

Here comes the sun

It's all right

It's all right 


\section{RESUMO}

O propósito do estudo realizado foi de investigar o comportamento voltamétrico da 3,4-metilenodioximetanfetamina (MDMA), substância psicoativa do ecstasy, uma droga que tem se tornado cada vez mais popular entre os usuários de drogas.

Empregou-se o uso da técnica de cromatografia líquida de alta eficiência, para isolar a substância a partir de amostras de ecstasy obtidas em parceria com a Polícia Científica de Ribeirão Preto, bem como a técnica de espectrometria de massas, para confirmar a presença da MDMA nas mesmas.

Os estudos voltamétricos foram realizados utilizando-se um sistema de três eletrodos, sendo o eletrodo de trabalho de carbono vítreo, eletrodo de referência $\mathrm{Ag} / \mathrm{AgCl}$ e eletrodo auxiliar de fio de platina. $\mathrm{O}$ comportamento eletroquímico desta substância foi investigado diante de diferentes modalidades voltamétricas: Voltametria cíclica, de pulso diferencial e de onda quadrada, nas quais se pôde observar um pico anódico em $E_{p}=+1,1 \mathrm{~V}$. Foram otimizados os parâmetros voltamétricos de modo a tornar a análise mais rápida e sensível, sem perda de intensidade e qualidade do sinal voltamétrico.

Com os parâmetros voltamétricos otimizados, foram construídas curvas analíticas para $\mathrm{o}$ analito em questão nas diferentes modalidades voltamétricas estudadas. Foi possível determinar o teor de MDMA nas cinco diferentes amostras de ecstasy utilizadas, das quais quatro apresentaram MDMA com teores variando de 3 a $10 \%(\mathrm{~m} / \mathrm{m})$ e uma na qual não foi constatada a presença da droga, mas sim de outro fármaco, a lidocaína.

Palavras-chave: MDMA; 3,4-metilenodioximetanfetamina; Ecstasy; Eletroquímica; Voltametria. 


\begin{abstract}
The main purpose of the present study was to investigate the voltammetric behavior of 3,4-methylenedioxymethanphetamine (MDMA), the psychoactive substance of ecstasy, a drug that has become increasingly popular among drug users.

The high performance liquid chromatography technique was employed in order to isolate the substance from ecstasy samples obtained in partnership with Polícia Científica de Ribeirão Preto and also the mass spectrometry technique was employed to confirm the presence of MDMA.

The voltammetric studies were performed using the three electrodes system, being glassy carbon as the working electrode, $\mathrm{Ag} / \mathrm{AgCl}$ as the reference electrode and platinum wire as counter electrode. The electrochemical behavior of the substance was investigated using different voltammetric techniques: Cyclic, differential pulse and square wave voltammetry modalities, in which an anodic peak was observed at $E_{p}=$ $+1,1 \mathrm{~V}$. The voltammetric parameters were optimized in order to make the analysis faster and more sensitive, without loss of quality and intensity of the voltammetric signal.

With the voltammetric parameters optimized, analytical curves of the studied analyte were built for the different voltammetric techniques. It was possible to determine the content of MDMA in the five different ecstasy samples utilized, in which four showed MDMA with contents ranging from 3 to $10 \%(\mathrm{~m} / \mathrm{m})$ and one in which no MDMA was observed but another drug, lidocaine.
\end{abstract}

Keywords: MDMA, 3,4-methylenedioxymethamphetamine; Ecstasy; Electrochemistry; Voltammetry. 


\section{SUMÁRIO}

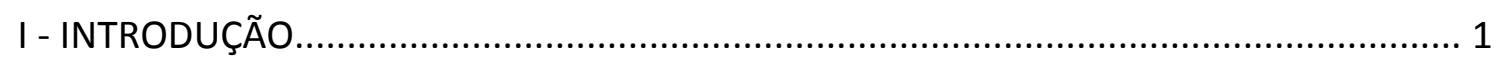

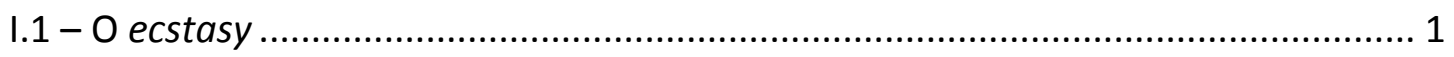

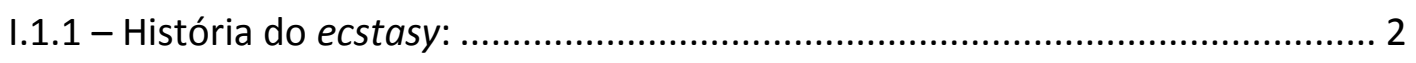

I.1.2 - Dados Químicos: ................................................................................. 3

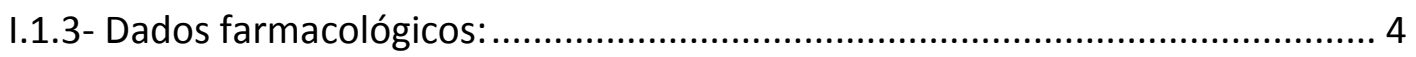

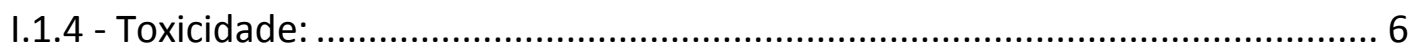

I.1.5 - Emprego terapêutico: ................................................................... 7

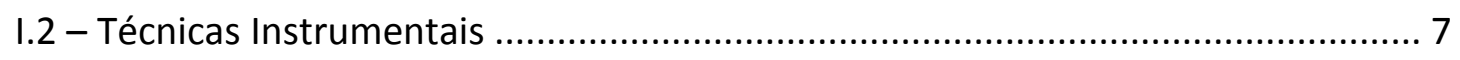

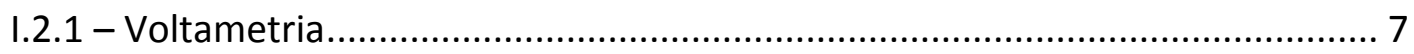

I.2.1.1 - O início da voltametria .............................................................. 9

I.2.1.2 - Instrumentação utilizada em voltametria ............................................ 9

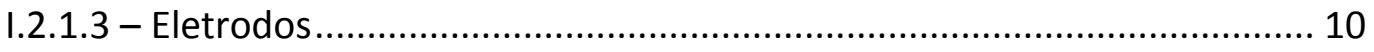

I.2.1.4 - Voltamogramas....................................................................... 10

I.2.2 - Cromatografia líquida de alta eficiência ............................................ 12

I.2.3 - Espectrometria de massas ............................................................ 13

I.3 - Análise da 3,4-metilenodioximetanfetamina por técnicas convencionais e as principais matrizes biológicas utilizadas em análise toxicológica ................................ 13

I.4 - Análise da 3,4-metilenodioximetanfetamina por técnicas eletroquímicas ........ 14

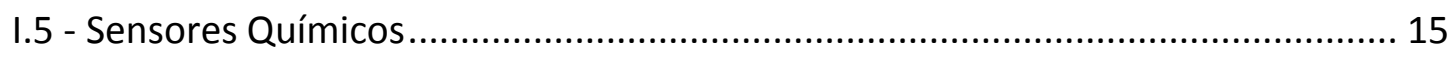

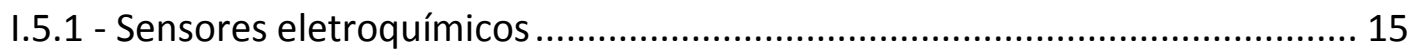

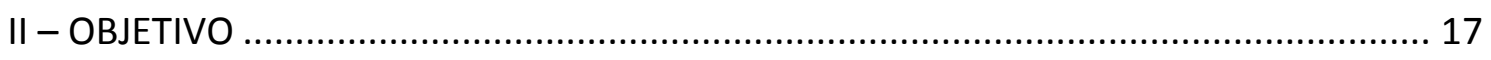

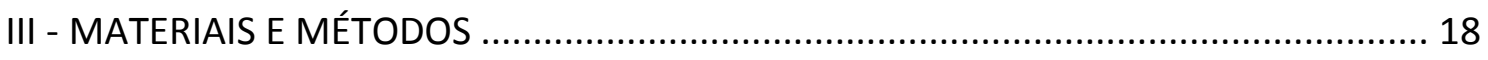

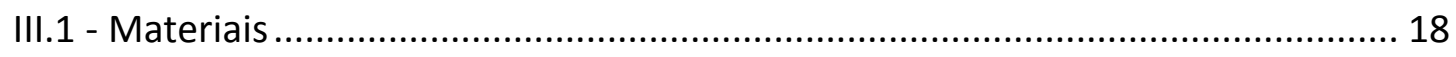

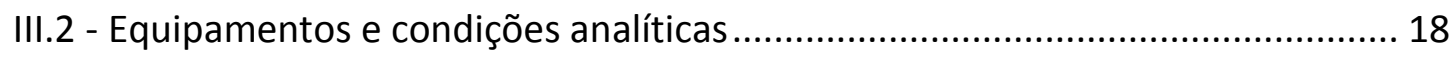




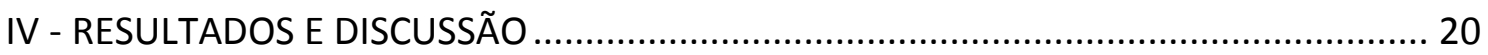

IV.1 - Obtenção de soluções padrão de MDMA por CLAE ...................................... 20

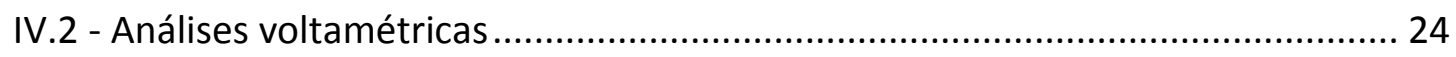

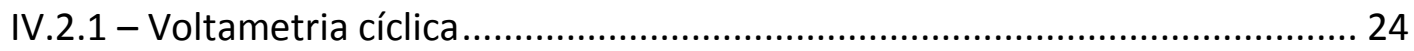

IV.2.2 - Voltametria de onda quadrada e voltametria de pulso diferencial .......... 26

IV.2.3 - Otimização dos parâmetros voltamétricos............................................. 29

IV.2.3.1 - Otimização dos parâmetros voltamétricos - Voltametria cíclica ....... 29

IV.2.3.2 - Otimização dos parâmetros voltamétricos - Voltametria de onda

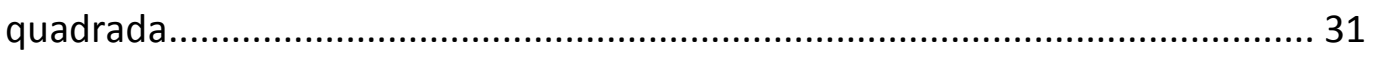

IV.2.3.3 - Otimização dos parâmetros voltamétricos - Voltametria de pulso

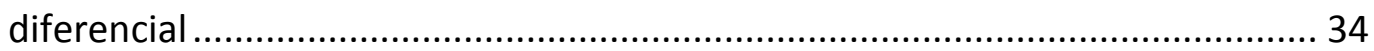

IV.2.3.4 - Otimização dos parâmetros voltamétricos - Etapa de préconcentração

IV.3 - Determinação do intervalo de trabalho e limites de detecção ........................ 40

IV.4 - Determinação do teor de MDMA nos comprimidos de ecstasy ...................... 45

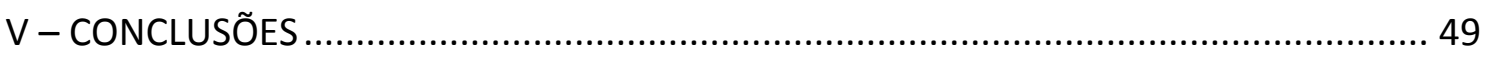

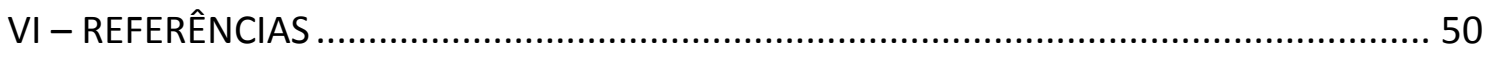




\section{I - INTRODUÇÃO}

\section{I.1 - O ecstasy}

O hábito de consumir drogas está presente na sociedade humana há vários milênios. Ainda que em alguns países sejam prescritas para tratamentos médicos, muitas destas drogas estão sujeitas a sínteses clandestinas e ao narcotráfico em todo o mundo.

O consumo e o tráfico internacional de ecstasy aumentaram em progressão geométrica desde a década de 90. Segundo dados do Escritório das Nações Unidas sobre Drogas e Crime (UNODC), em 2006 existiam aproximadamente 24,7 milhões de usuários de drogas equivalente a 0,6\% da população mundial com idade entre 15 e 64 anos. Deste grupo, 9 milhões seriam usuários de ecstasy. No ano de 2009, cerca de 0,4\% da população mundial com mais de 15 anos fizeram ao menos uma vez uso deste entorpecente. Para o Brasil os dados referentes ao número de usuários de ecstasy são incertos, mas estima-se que $0,2 \%$ da população da América do Sul tenha feito uso da mesma no ano de $2008^{[1]}$.

As apreensões de comprimidos de ecstasy têm crescido desde sua primeira apreensão em 1995. Durante o ano 2001 foram apreendidos 1.061 comprimidos pela Polícia Civil do Estado de São Paulo; no ano seguinte este número foi de 5.677. Em nível nacional, em 2004 foram apreendidos 81.971 comprimidos da droga, número este que quase triplicou no ano de 2007 quando foram apreendidas 211.145 unidades. Nos anos seguintes, os números de comprimidos apreendidos caíram consideravelmente (132.633 em 2008, 28.312 em 2009 e 2.740 em 2010), mas ainda assim, não deixando de ser um fator preocupante ${ }^{[2]}$.

O ecstasy é comumente encontrado na forma de comprimidos, com variedades de cores, formas e tamanhos, além de figuras e logotipos (figura 1). Outra variável quanto ao ecstasy vendido ilegalmente está na sua composição. Seu princípio ativo é a 3,4-metilenodioximetanfetamina (MDMA), podendo existir grande variação no que diz respeito à sua quantidade (contêm cerca de 50-150 mg) e à presença de 
adulterantes como cafeína, efedrinas, paracetamol, cetamina e compostos análogos como a anfetamina, a metanfetamina, a 3,4-metilenodioxianfetamina (MDA) e a 3,4metilenodioxietilanfetamina (MDEA), substâncias adicionadas ao comprimido para mimetizar e/ou potencializar os efeitos induzidos pela MDMA ${ }^{[3-6]}$.

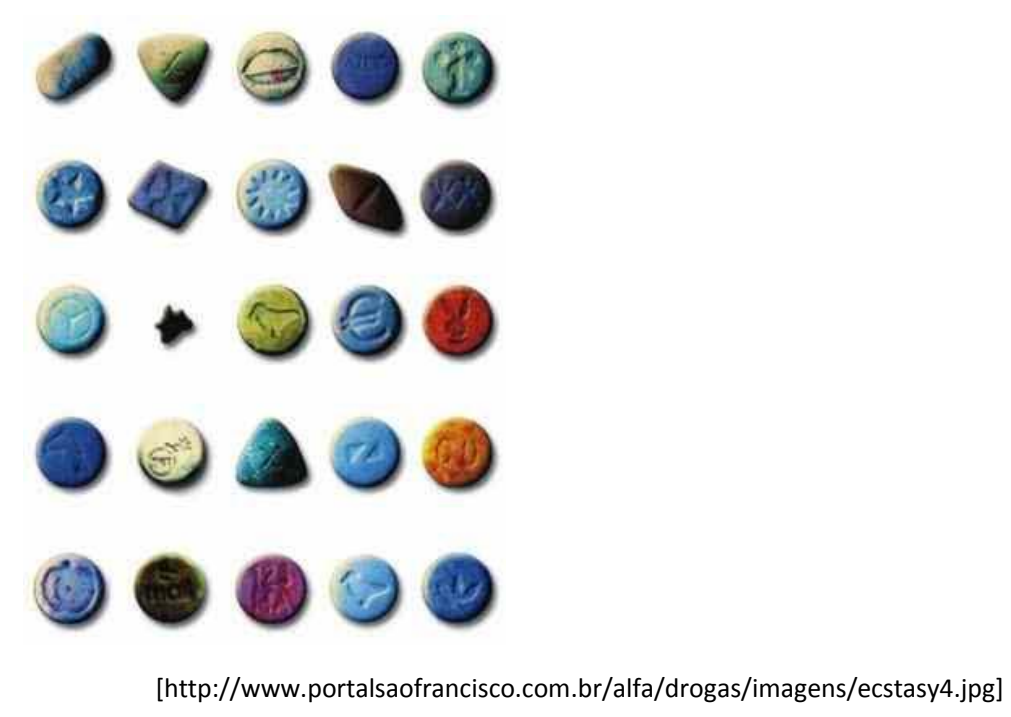

Figura 1 - Comprimidos de ecstasy de diferentes cores, tamanhos, formas e logotipos.

\section{I.1.1 - História do ecstasy:}

A 3,4-metilenodioximetanfetamina foi sintetizada pela primeira vez em 1912 e patenteada dois anos mais tarde (patente \#274.350) pela indústria farmacêutica alemã $\operatorname{Merck}^{\circledR}{ }^{[7,8]}$, com o propósito de agir como um inibidor de apetite, chegando ainda a ser distribuído para soldados durante a Primeira Guerra Mundial ${ }^{[8]}$. No entanto, permaneceu esquecida até a década de sessenta, quando passou a ser receitada por psicanalistas a seus pacientes como um antidepressivo.

Mas foi na década de setenta que começou a ser usada de forma recreativa, principalmente em festas e casas noturnas, foi quando ficou conhecida como "a droga do amor". Devido ao grande aumento da sua popularidade, ela ganhou também a atenção das autoridades, vindo a ser classificada como droga alucinógena e, consequentemente, proibida (em 1977 no Reino Unido e 1985 nos EUA) ${ }^{[9]}$. Nos 
últimos anos, o uso do ecstasy vem aumentando cada vez mais, sendo amplamente utilizado por frequentadores de festas e raves, geralmente jovens.

\section{I.1.2 - Dados Químicos:}

A MDMA (3,4-metilenodioximetanfetamina), também chamada como $\mathrm{N}$ metil-1-(3,4-metilenodioxifenil)-2-aminopropano (figura 2) é uma anfetamina do tipo anel-substituído e é estruturalmente relacionado à substância estimulante psicomotora anfetamina e à substância alucinógena mescalina ${ }^{[10]}$. Como as anfetaminas, a MDMA tem um centro quiral no carbono alfa e desta forma, existe como um par de isômeros ópticos. As configurações para os isômeros dextrógiros e levógiros são S-( + ) e R-( - ), respectivamente, com o isômero dextrógiro tendo maior atividade central ${ }^{[11]}$. O padrão de substituição do anel da MDMA difere das anfetaminas de potência alucinógena como a 2,5-dimetoxi-4-metilanfetamina (DOM), as quais são invariavelmente mais ativas em sua forma levógira ${ }^{[12,13]}$.

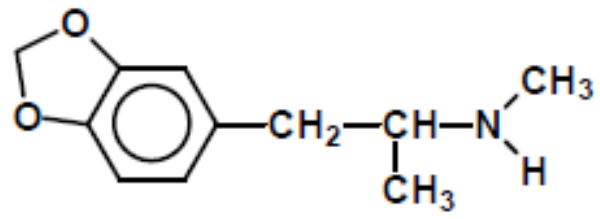

Figura 2 - Estrutura química da MDMA (3,4-metilenodioximetanfetamina).

Outras fenilalquilaminas análogas à MDMA como 3,4metilenodioxietilanfetamina (MDEA), 3,4-metilenodioxianfetamina (MDA), metanfetamina e anfetamina, já foram identificadas em vários comprimidos de ecstasy (figura 3) ${ }^{[14]}$. 
O

MDEA

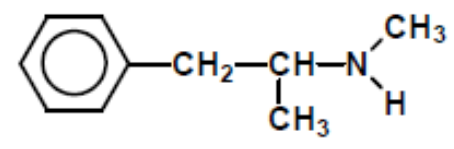

Metanfetamina<smiles>CC(C)NCc1ccc2c(c1)OCO2</smiles>

MDA

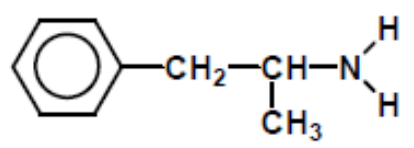

Anfetamina

Figura 3 - Estruturas químicas de fenilalquilaminas análogas à MDMA.

A síntese química da MDMA pode ser realizada a partir da metanfetamina em laboratórios apropriados, no entanto, pode ser simplificada quando utilizado o safrol, constituinte ativo encontrado em uma variedade de óleos essenciais, em especial do sassafrás, além da noz-moscada, canela, açafrão, cálamo, endro e semente de salsa, como precursor químico para a síntese ${ }^{[15]}$. Nesta substância, o grupo metilenodioxi (O-CH2-O-) ligado nas posições 3 e 4 do anel aromático (anel-substituído) é o mesmo que o encontrado na MDMA ${ }^{[19]}$.

\section{I.1.3- Dados farmacológicos:}

A MDMA apresenta efeitos adversos agudos semelhantes aos da cocaína e anfetaminas e, desta forma, pode ser classificada como um psicoestimulante ${ }^{[17]}$. A American Psychiatric Association (Associação Americana de Psiquiatria) considera a MDMA como uma substância alucinógena, entretanto não apresenta estrutura, atividade e efeitos subjetivos (alucinações, distorção no senso de tempo, nas percepções, entre outras) relacionadas com os alucinógenos semelhantes ao LSD (dietilamida do ácido lisérgico), a não ser quando consumido em doses extremamente altas $^{[17]}$. 
A MDMA é uma neurotoxina seletiva serotonérgica, a qual tem grande afinidade com os receptores de serotonina e locais de transporte no cérebro ${ }^{[18]}$. A serotonina é um neurotransmissor que faz controle das emoções, do domínio sensorial e da capacidade associativa do cérebro. É também importante na memória e na regulação da temperatura corporal ${ }^{[19,20]}$. Quando administrada, a MDMA faz com que haja um aumento na liberação de neurotransmissores monoaminas (dopamina, noradrenalina e serotonina), pois se liga diretamente ao axônio, o que impede a produção e liberação de monoaminas, diminuindo a concentração destas no cérebro ${ }^{[7]}$.

É provável que exista mais de um mecanismo de ação da MDMA, envolvendo serotonina $(5-\mathrm{HT})$, noradrenalina e dopamina ${ }^{[3,7]}$. Inicialmente, a MDMA promove um aumento na liberação de serotonina (5-HT) na fenda sináptica ao mesmo tempo em que diminui a sua recaptação pela membrana pré-sináptica. Por outro lado, provoca uma diminuição na atividade da enzima triptofano hidroxilase (TPH), que é a responsável por uma das etapas da síntese da 5-HT, resultando em uma diminuição nos estoques de 5-HT nas vesículas pré-sinápticas e consequentemente do seu metabólito o ácido 5-hidroxindolacético ${ }^{[21,22]}$.

Os efeitos alucinógenos atribuídos à MDMA parecem estar relacionados com sua grande afinidade pelo receptor $5-\mathrm{HT}_{2 \mathrm{~A}}$, que é considerado o responsável pelos efeitos provocados pela substância alucinógena clássica, a dietilamida do ácido lisérgico $(L S D)^{[23,25]}$. Embora a serotonina seja o principal neurotransmissor relativo aos efeitos psíquicos provocados pela MDMA, a dopamina também esta envolvida, uma vez que sua síntese e liberação ficam aumentadas com a ativação do receptor 5$\mathrm{HT}_{2 \mathrm{~A}}{ }^{[22,24]}$.

A noradrenalina, por sua vez, é a principal responsável pelos efeitos físicos observados, os quais se parecem muito com os provocados pelas anfetaminas ${ }^{[3,7]}$. Com relação aos efeitos cardiovasculares provocados pela MDMA, ou seja, hipertensão, arritmia e aumento da frequência cardíaca, podem ser explicados pela afinidade de interação da MDMA com o receptor $\alpha-2$ adrenérgico ${ }^{[23,25]}$. 


\section{I.1.4 - Toxicidade:}

Usuários descrevem os efeitos do ecstasy como uma sensação de proximidade e intimidade com outras pessoas ao redor, melhorando o relacionamento e a comunicação entre elas, uma sensação de euforia com aumento da energia emocional e física, além de uma elevação da autoestima que, de forma geral, são conseguidos com doses baixas e em episódios isolados de uso ${ }^{[13,14,15]}$.

Os efeitos conhecidos da MDMA variam de acordo com a dose, frequência e duração de uso, podendo ser agudos ou crônicos. Os efeitos físicos são: acentuação de insônia, paciência e tolerância (resistência), adiando a fadiga e sonolência, excesso de energia e desinibição sexual. Os efeitos psicológicos como euforia, sensação de bem estar, percepção sensorial acentuada, maior sensação de proximidade com outrem, além de outras perspectivas e sentimentos são observados ${ }^{[7,19]}$. São descritos ainda, efeitos negativos como aumento de tensão (tensão muscular), espasmos musculares que incluem um bater de dentes constante e aperto das maxilas ${ }^{[7,18,19]}$. Observa-se aumento da temperatura corporal devido ao aumento da atividade muscular, em consequência da ação da droga no sistema termorregulador do cérebro. Outros efeitos também são observados durante ou após o uso da droga como dor de cabeça, perda de apetite, falta de saliva, variações de humor, náuseas, fadiga e visão difusa ${ }^{[18]}$.

Ainda não estão completamente compreendidos os mecanismos de neurotoxicidade do MDMA. Indícios como danos cerebrais irreversíveis, que independem de um longo uso de MDMA, levam a crer que exista neurotoxicidade irreversível elevada nos consumidores de ecstasy. Estudos ainda estão sendo desenvolvidos para se avaliar as consequências funcionais a longo prazo, que ainda permanecem incertas ${ }^{[20]}$. Os efeitos mais significativos conhecidos do uso de ecstasy são hipertermia e hipotermia, que são potencialmente letais ${ }^{[19]}$.

Ainda não se sabe se o ecstasy provoca dependência nos usuários, o que é uma questão difícil de ser estudada devido a questões éticas, tais como a obtenção da droga, permitir o uso controlado em voluntários, controle dos efeitos da substância, etc. $^{[20]}$ 


\section{I.1.5 - Emprego terapêutico:}

Alguns pesquisadores sugerem que a MDMA pode ser útil na psicoterapia, facilitando o autoexame com redução do medo ${ }^{[21-23]}$. No entanto, alguns terapeutas utilizavam MDMA em suas consultas até ser tornada ilegal. Em alguns experimentos realizados ${ }^{[24]}$, os autores reportam que os pacientes tiveram melhoria em alguns transtornos psiquiátricos suaves e também outros benefícios pessoais, especialmente quanto à comunicação íntima com outrem. Há ainda, indícios de que a MDMA seja aliviadora de dor para pacientes com câncer terminal ${ }^{[25]}$. No entanto, ainda não se conhece muito bem os efeitos do MDMA como substância terapêutica e são necessários maiores estudos sobre o assunto, como vem realizando a Associação Multidisciplinar para Estudos Psicodélicos (MAPS) ${ }^{[26]}$.

\section{2 - Técnicas Instrumentais}

As técnicas instrumentais fazem uso de equipamentos analíticos capazes de detectar e registrar dados relativos aos analitos. Entre as técnicas utilizadas neste estudo estão a voltametria, a cromatografia líquida de alta eficiência e a espectrometria de massas.

\section{I.2.1 - Voltametria}

Entre as técnicas analíticas em eletroquímica, certamente a voltametria é uma das mais poderosas e versáteis, a qual permite obter informações qualitativas e quantitativas a respeito de um determinado analito, bem como a respeito de mecanismos de reações de oxi-redução ${ }^{[27]}$.

"A voltametria é um conjunto de técnicas nas quais se observa a relação entre corrente e potencial durante os processos eletroquímicos envolvidos" (Harris, 2001, p.376) ${ }^{[28]}$. De modo geral, aplica-se um potencial que varia linearmente conforme o 
tempo (figura 4.a) sob condições que promovam a polarização do eletrodo de trabalho e monitora-se a intensidade da corrente resultante que flui através da célula eletroquímica. O gráfico que relaciona corrente e potencial é chamado de voltamograma (figura 4.b) ${ }^{[27]}$.

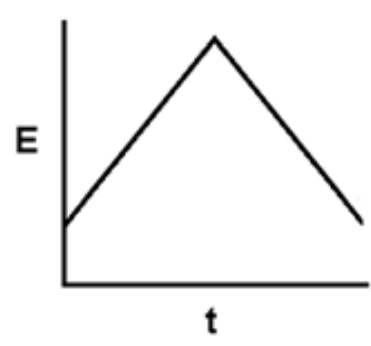

(a)

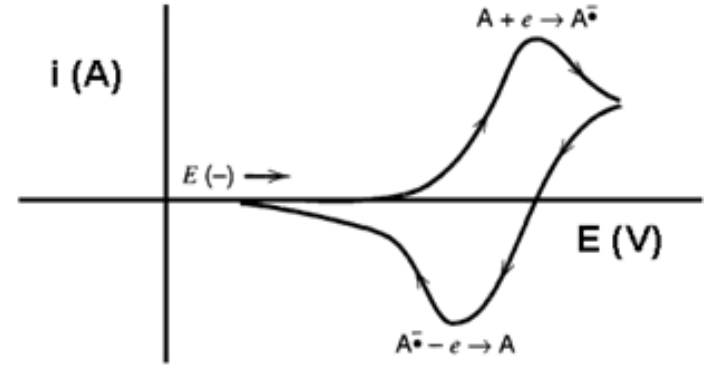

(b)

Figura $4^{[31]}$ - a) Exemplo de variação entre potencial e tempo (voltametria cíclica). b) Voltamograma de uma reação genérica de oxi-redução (voltametria cíclica).

Para cada técnica (modalidade) voltamétrica, a forma como o potencial varia com o tempo será diferente e é este fato que confere as diferentes características de cada modalidade. Essas funções de potencial-tempo são chamadas de sinais de excitação e possuem diferentes formas de onda que podem ser aplicadas ao eletrodo, sendo diferentes modos de varreduras lineares, pulsadas e triangulares (figura 5$)^{[27]}$.

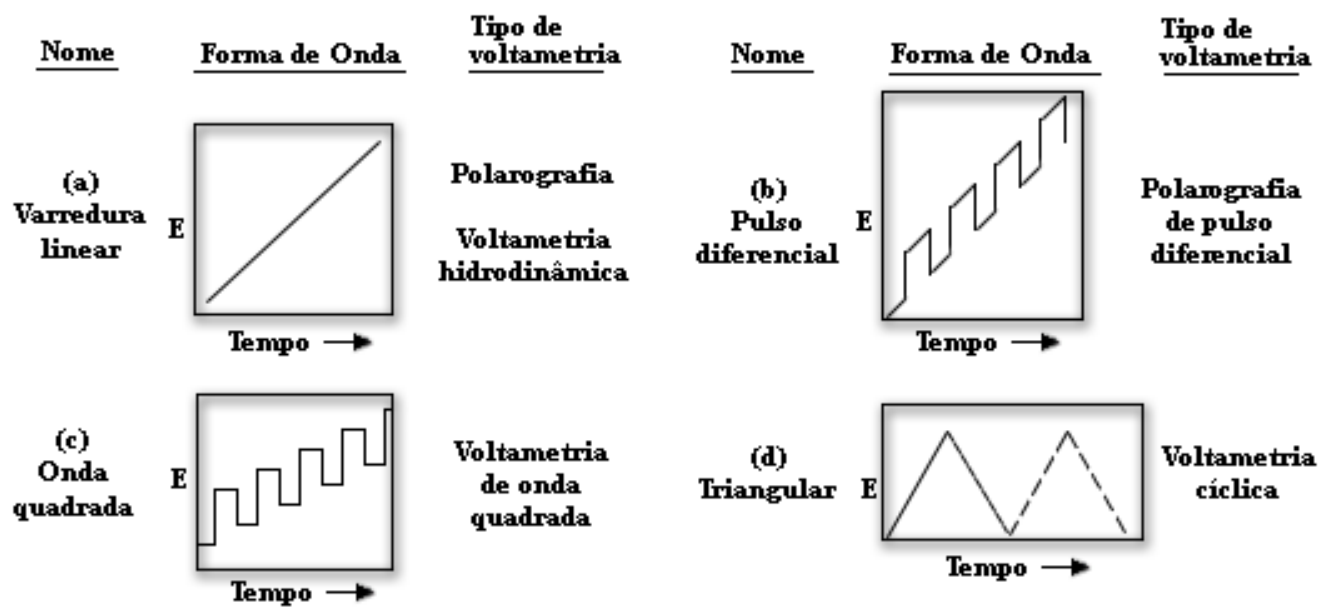

Figura $5^{[31]}$ - Os quatro sinais de excitação mais comuns em voltametria (potencial versus tempo). 


\section{I.2.1.1 - O início da voltametria}

A voltametria tem seu início na polarografia, técnica criada pelo checo Jaroslav Heyrovsky (1880-1967) em 1912, invenção a qual lhe rendeu o prêmio Nobel de Química em 1959. A principal característica desta técnica é a utilização de um eletrodo gotejante de mercúrio como eletrodo de trabalho, onde o potencial varia linearmente com o tempo, com forma de onda idêntica à técnica de voltametria linear (figura 5.a). O gráfico resultante da relação obtida entre potencial aplicado e corrente gerada medida recebe o nome de polarograma (figura 6) ${ }^{[27]}$.

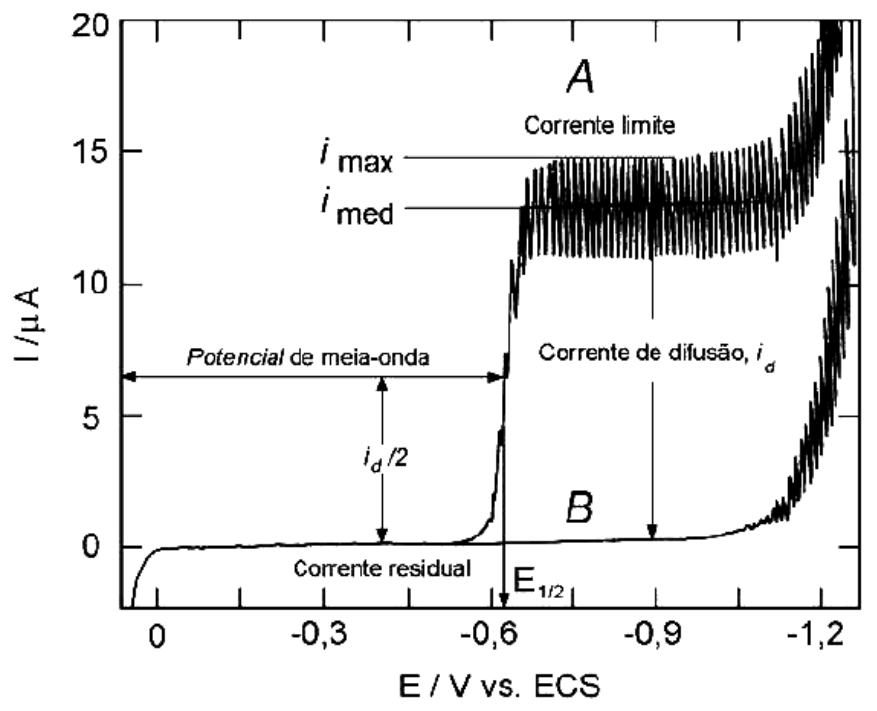

Figura $6^{[31]}$ - Polarogramas de $(\mathrm{A})$ solução $5 \times 10^{-4} \mathrm{~mol} \mathrm{~L}^{-1}$ de $\mathrm{Cd}^{2+}$ em $\mathrm{HCl} 1 \mathrm{M}$ e (B) solução de $\mathrm{HCl} 1 \mathrm{M}$.

\section{I.2.1.2 - Instrumentação utilizada em voltametria}

Os componentes básicos de um sistema eletroanalítico moderno para voltametria são um potenciostato, um computador e a célula eletroquímica. O papel do potenciostato é aplicar o potencial conhecido ao eletrodo de trabalho e monitorar a corrente gerada. No computador são ajustados os parâmetros voltamétricos, bem como a forma de onda do sinal de excitação e é onde são visualizados os dados obtidos. A célula voltamétrica apresenta o sistema de eletrodos, os quais são imersos 
na solução que contém o analito dissolvido em um solvente e o eletrólito suporte, que pode ser o próprio solvente (eletrólito inerte) ${ }^{[27]}$.

\section{I.2.1.3 - Eletrodos}

O sistema de eletrodos moderno é composto por três tipos de eletrodos: eletrodo de trabalho, eletrodo auxiliar (ou contra eletrodo) e eletrodo de referência. Os eletrodos existem em diferentes tamanhos, formatos e materiais, o que lhes confere diferentes características ${ }^{[29]}$.

O eletrodo de trabalho é um eletrodo polarizável no qual será aplicado frente ao eletrodo de referência o potencial que promoverá as reações eletroquímicas do analito. Os eletrodos mais comuns são os de carbono vítreo, platina e de mercúrio (eletrodo gotejante de mercúrio) ${ }^{[29]}$.

O eletrodo de referência é um eletrodo que possui grande área superficial, para que não seja polarizado e mantenha seu potencial constante. Os eletrodos de referência mais comuns são o eletrodo de calomelano saturado (ECS) e o eletrodo de prata/cloreto de prata $(\mathrm{Ag} / \mathrm{AgCl})^{[29]}$.

O eletrodo auxiliar (ou contra eletrodo) está presente no sistema para assegurar que o eletrodo de referência não seja polarizado. Os eletrodos auxiliares consistem em um material condutor e quimicamente inerte, sendo o eletrodo de platina o mais comum ${ }^{[29]}$.

\section{I.2.1.4 - Voltamogramas}

Como já foi mencionado anteriormente, os voltamogramas são os gráficos que relacionam o potencial aplicado sobre o eletrodo com a corrente gerada (figura 7) [27]. 
Os parâmetros mais importantes nos voltamogramas são a corrente de pico $\left(i_{p}\right)$ e o potencial de pico $\left(E_{p}\right)$, sendo o primeiro referente ao tamanho do pico, o qual é medido traçando-se uma reta a partir da linha base do pico e outra reta perpendicular a esta a partir do topo do pico e o segundo, o potencial no qual o pico tem seu valor máximo ${ }^{[27]}$.

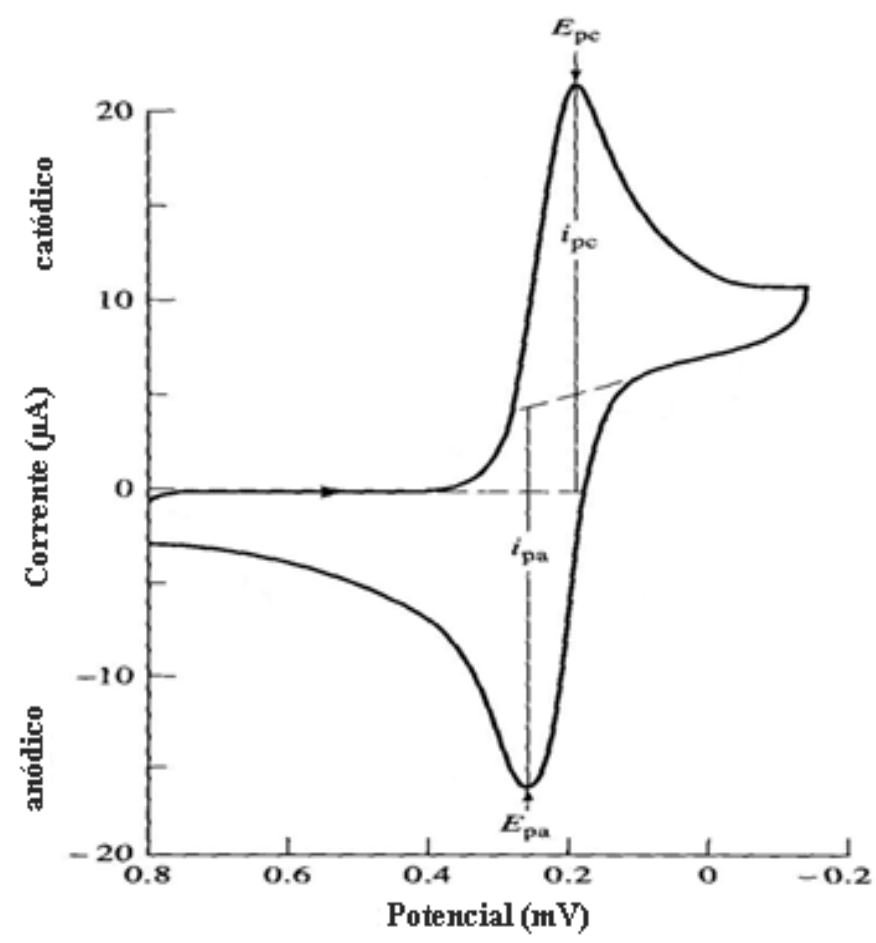

Figura $7^{[31]}-$ Voltamograma cíclico da reação de oxi-redução de $\mathrm{Fe}(\mathrm{CN})_{6}{ }^{3-} \rightleftharpoons \mathrm{Fe}(\mathrm{CN})_{6}{ }^{4-}$ exibindo os parâmetros de potenciais e correntes de pico.

Em voltametria cíclica, as reações reversíveis apresentam corrente de pico relacionadas com a concentração da espécie eletroativa $\left(a 5^{\circ} \mathrm{C}\right)$, segundo a equação de Randles-Sevcik (equação 1) ${ }^{[30]}$ :

$$
i_{p}=\left(2,69 \times 10^{5}\right) n^{2 / 3} A D_{0}^{1 / 2} v^{1 / 2} C_{0}
$$

Equação 1 - Equação de Randles-Sevcik. $\mathrm{n}=$ número de elétrons, $\mathrm{A}=$ área do eletrodo $\left(\mathrm{cm}^{2}\right), \mathrm{C}=$ concentração da espécie eletroativa $\left(\mathrm{mol} / \mathrm{cm}^{3}\right), D=$ coeficiente de difusão $\left(\mathrm{cm}^{2} / \mathrm{s}\right), v=$ velocidade de varredura $(\mathrm{V} / \mathrm{s})$. 


\section{I.2.2 - Cromatografia líquida de alta eficiência}

A cromatografia líquida de alta eficiência (CLAE) ou high performance liquid chromatography (HPLC) é uma importante ferramenta de separação dos componentes de uma mistura. A separação nessa técnica ocorre pela interação entre a fase móvel, que é constituída por um solvente líquido, no qual a mistura que se busca a separação está solubilizada e a fase estacionária da coluna de separação que pode ser sólida ou líquida ${ }^{[31]}$.

Esta técnica faz uso de elevadas pressões para tornar a eluição da fase móvel mais rápida, além de ser altamente e versátil, permitindo a separação e detecção de materiais orgânicos, inorgânicos e biológicos. A sensibilidade desta técnica é limitada pelo detector empregado, mas pode ser altamente sensível, sendo capaz de separar e detectar analitos em concentrações da ordem de parte por trilhão (ppt) ${ }^{[31]}$.

O gráfico obtido em uma análise cromatográfica relaciona a intensidade do sinal cromatográfico com o tempo de eluição e recebe o nome de cromatograma (figura 8) ${ }^{[31]}$.

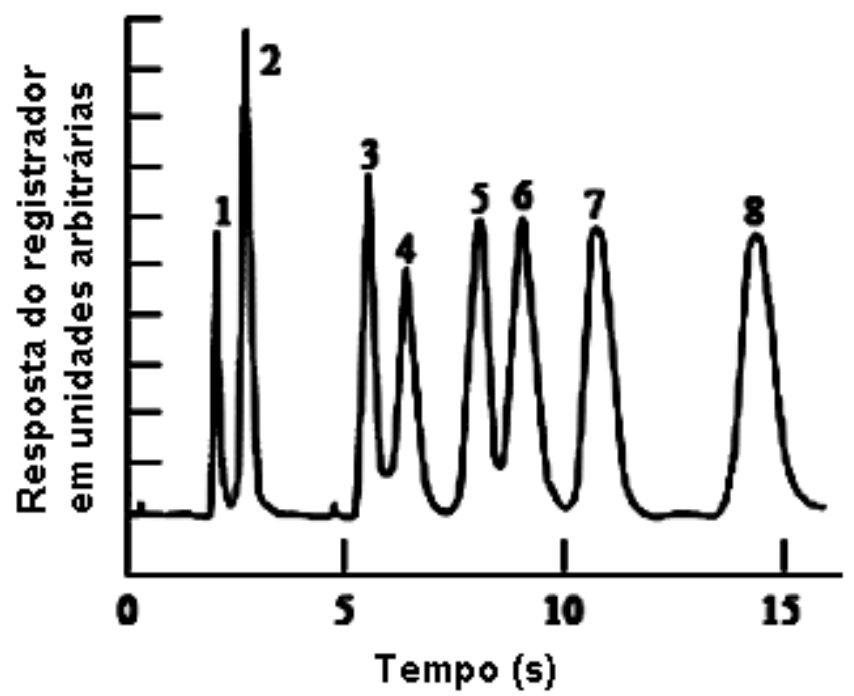

Figura $8^{[31]}$ - Cromatograma de uma separação genérica de oito componentes de uma mistura. 


\section{I.2.3 - Espectrometria de massas}

A espectrometria de massas é uma técnica analítica que permite a determinação da massa molar de compostos químicos. Seu princípio se baseia na detecção de compostos eletricamente carregados, ou seja, ionizados, sendo tais íons detectados de acordo com sua razão massa/carga $(\mathrm{m} / \mathrm{z})^{[32]}$.

Os espectrômetros de massas apresentam como componentes básicos: sistema de introdução de amostras, uma fonte de íons (ionizador), um analisador de massas, um detector e um registrador (figura 9) ${ }^{[32]}$.

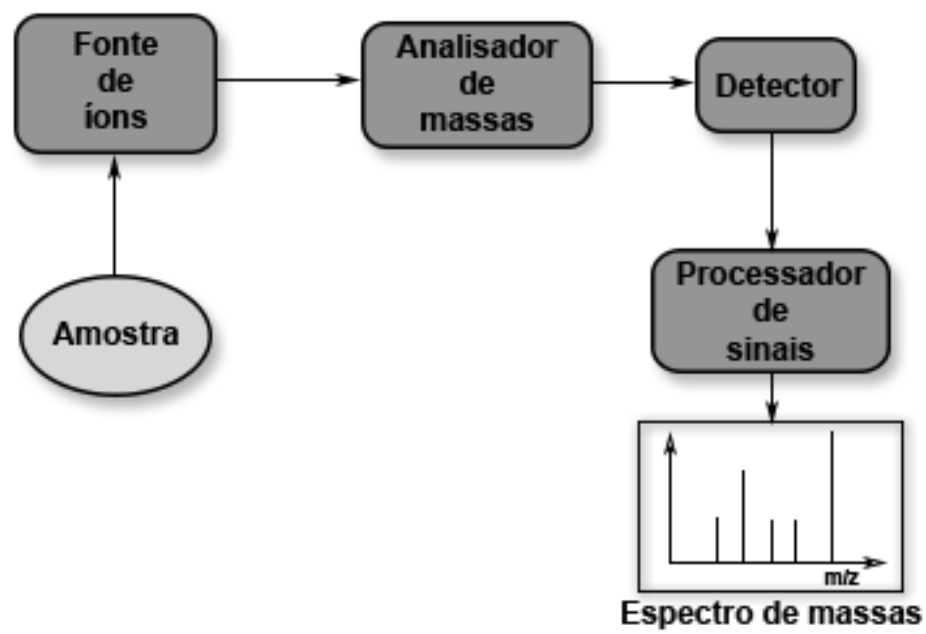

Figura 9 - Esquema de funcionamento dos componentes básicos de um espectrômetro de massas.

\section{I.3 - Análise da 3,4-metilenodioximetanfetamina por técnicas convencionais} e as principais matrizes biológicas utilizadas em análise toxicológica

As principais técnicas utilizadas para a análise da MDMA e outras anfetaminas são cromatografia gasosa (CG) ou cromatografia líquida de alta eficiência (CLAE), acopladas a um espectrômetro de massas, as quais podem ser utilizadas para análise no soro ${ }^{[33]}$, na urina ${ }^{[34,35]}$, cabelos $^{[36,37]}$, saliva ${ }^{[38,39]}$ e suor ${ }^{[40]}$, mas que requerem uma etapa de isolamento por extração líquido-líquido ${ }^{[3,35,37]}$ ou extração em fase sólida e 
uma etapa de derivatização ${ }^{[36-40]}$. Este pré-tratamento das amostras torna a análise mais longa e cara.

A cromatografia líquida acoplada à espectrometria de massas em tandem (conjunto de três espectrômetros de massas com analisador quadrupolar, sendo dois quadrupolos de filtragem, e um terceiro, central, a câmara de colisão, permitindo reconhecer pares transicionais, como por exemplo, o espectro de todos os íons precursores de um determinado produto) oferece vantagens consideráveis por apresentar poderosa performance quanto à velocidade, seletividade, sensitividade e robustez. A preparação das amostras é mais simples, a qual geralmente inclui precipitação de proteínas e/ou extração anterior à análise cromatográfica ${ }^{[41]}$.

\section{I.4 - Análise da 3,4-metilenodioximetanfetamina por técnicas eletroquímicas}

GARRIDO $^{[42]}$ em seu estudo eletroquímico de algumas anfetaminas mostrou através da técnica de voltametria por pulso diferencial que a substância anfetamina não é eletroativa sobre todo o intervalo de $\mathrm{pH}$ estudado, uma vez que sua estrutura molecular possui apenas um grupo funcional, uma amina alifática primária. Essas aminas geralmente se oxidam em potencial superior a aqueles permitidos pela janela de potencial dos eletrodos de carbono vítreo. Para a metanfetamina, uma única onda anódica pode ser observada acima de $\mathrm{pH} 9, \mathrm{E}_{\mathrm{p}}=+0,92 \mathrm{~V}$, correspondente à oxidação da amina secundária presente na molécula de metanfetamina. É considerado que o primeiro passo na oxidação de aminas alifáticas em soluções aquosas seja a abstração de um elétron do par de elétrons do nitrogênio da amina. Através de voltamogramas cíclicos, observou-se que a oxidação deste composto é irreversível e não se observa pico de redução.

Para a MDMA, foi observado um primeiro pico anódico correspondente à oxidação do núcleo aromático da molécula, levando à formação e um cátion radical em $E_{p}=+1,18 \mathrm{~V}$, iniciando em $\mathrm{pH} 2$. Um segundo pico anódico em $E_{p}=+1,31 \mathrm{~V}$ iniciando em pH 4 pode ser visualizado, correspondente à oxidação de uma espécie formada por 
dimerização do cátion radical formado inicialmente. Acima de $\mathrm{pH}$ 9, outro pico anódico é observado em $E_{p}=+0,86 \mathrm{~V}$, correspondendo à oxidação da amina secundária presente na molécula da MDMA. Este pico relaciona-se com as propriedades ácidobase da molécula. De fato, neste $\mathrm{pH}$ ocorre desprotonação da amina secundária e, como resultado, um processo oxidativo pode ocorrer devido à existência do par de elétrons. O mesmo autor descreve ainda, a utilização do método para análise quantitativa, mostrando boa relação linear entre concentração e intensidade de pico.

\section{5 - Sensores Químicos}

Os sensores são dispositivos capazes de detectar sinais ou receber estímulos de natureza física ou química. O sistema de sensoriamento é constituído por três partes: sensor, transdutor ou amplificador e condutor ${ }^{[43]}$. Tais sensores podem ser ópticos, elétricos, de massa ou térmicos.

\section{I.5.1 - Sensores eletroquímicos}

Os sensores eletroquímicos baseiam-se em reações de transferência de carga (processos faradáicos) ou em fenômenos de migração de carga (não faradáico). Estes podem ser sensores ou biossensores, respeitando a sua natureza ${ }^{[44]}$. Os sensores eletroquímicos têm sido extensivamente aplicados nos setores industrial, farmacêutico, ambiental, dentre outros ${ }^{[45]}$. Tais sensores podem ser subdivididos em quatro classes principais: sensores potenciométricos, condutométricos, amperométricos e voltamétricos.

Sensores potenciométricos baseiam-se na medida do potencial elétrico gerado na interface solução/sensor, considerando que na solução estejam presentes espécies aptas a interagir com a superfície do sensor, como os eletrodos íons seletivos, por exemplo ${ }^{[46]}$. Em relação aos sensores condutométricos baseiam-se na medida da condutividade elétrica. Um exemplo a ser citado destes sensores são aqueles a base de 
semicondutores para gases ${ }^{[43]}$. Aqueles sensores que constituem na medida de corrente são denominados amperométricos. Nas técnicas que utilizam estes sensores, aplica-se um potencial fixo suficiente para efetivação de um processo redox na cela eletroquímica $^{[43]}$.

Pode-se utilizar os sensores voltamétricos tanto em análises quantitativas quanto qualitativas na caracterização e no estudo de mecanismo de oxidação e redução. Neste tipo de técnica faz-se o monitoramento dos níveis de corrente em função do potencial ${ }^{[47]}$, entretanto, a faixa de varredura deve ser escolhida de acordo com o objetivo, ressaltando que, para análises quantitativas, quanto menor for o potencial (valores próximos a zero), menores serão os problemas com interferentes [48].

Neste trabalho, foi realizado o estudo voltamétrico da MDMA em condições analíticas diferentes das encontradas na literatura, exploradas por outros pesquisadores. 
II - OBJETIVO

Este trabalho teve por objetivo, desenvolver e validar uma metodologia de análise voltamétrica através das técnicas de voltametria cíclica, voltametria de onda quadrada e voltametria de pulso diferencial da 3,4-metilenodioximetanfetamina (MDMA), bem como da determinação do teor da mesma em amostras de ecstasy apreendidas pela polícia pelo uso destas mesmas técnicas. 


\section{III - MATERIAIS E MÉTODOS}

\section{III.1 - Materiais}

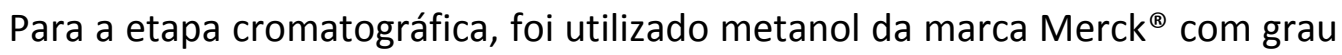
de pureza apropriado para cromatografia líquida de alta eficiência (CLAE) e água grau Milli-Q. Nos experimentos de voltametria, foram utilizados dihidrogenofosfato de potássio e hidrogenofosfato de potássio da marca J.T.Baker ${ }^{\circledast}$. As análises das amostras de ecstasy foram realizadas em parceria com a Polícia Científica de Ribeirão Preto. A solução padrão de MDMA em metanol utilizada foi da marca Cerilliant ${ }^{\circledR}$ com concentração de $1,0 \mathrm{mg} / \mathrm{mL}$.

\section{III.2 - Equipamentos e condições analíticas}

O equipamento de CLAE utilizado foi da marca Shimadzu com detector SPD20A ajustado em comprimento de onda de $288 \mathrm{~nm}$ e coletor automático FRC-10A, sendo as colunas cromatográficas Shim-pack $5 \mu 250 \times 4.60 \mathrm{~mm}$ (coluna analítica) e $19 \mathrm{x}$ $250 \mathrm{~mm}$ (coluna preparativa). O volume de amostra injetado na etapa analítica foi de $10 \mu \mathrm{L}$ com concentração de $2,5 \mathrm{mg} / \mathrm{mL}$ e o volume da amostra injetado na etapa preparativa foi de $500 \mu \mathrm{L}$ com concentração de $220 \mathrm{mg} / \mathrm{mL}$. Utilizou-se como fase móvel gradiente de $\mathrm{H}_{2} \mathrm{O}+0,1 \%$ acetato de amônio e metanol $+0,1 \%$ acetato de amônio (tabela 1). A vazão utilizada foi de $0,6 \mathrm{~mL} / \mathrm{min}$ para a etapa analítica e 11,3 $\mathrm{mL} / \mathrm{min}$ para a etapa preparativa.

Tabela 1 - Composição do gradiente utilizado em CLAE. ( $B$ = metanol + 0,1\% acetato de amônio)

\begin{tabular}{cc}
$\begin{array}{c}\text { Tempo } \\
\text { (min) }\end{array}$ & \% de B \\
\hline 0 & 10 \\
10 & 30 \\
25 & 70 \\
26 & 70 \\
27 & 10 \\
30 & 10 \\
\hline
\end{tabular}


Foi utilizado o espectrômetro de massas com ionização por electrospray da marca Varian 1200L - quadrupole MS/MS com auto injetor ProStar, Modelo 410. 0 volume injetado das amostras foi de $20 \mu \mathrm{L}$ com concentração de $50 \mu \mathrm{g} / \mathrm{mL}$ e fase móvel de $\mathrm{H}_{2} \mathrm{O} /$ metanol $+0,1 \%$ acetato de amônio (proporção de 1:9). $\mathrm{O}$ equipamento foi ajustado em modo positivo $(\mathrm{ESI}+)$, voltagem do capilar = 40V; $\mathrm{Q} 0=-1,6 \mathrm{~V} ; \mathrm{Q} 1=-1,1 \mathrm{~V}$; $\mathrm{Q} 2=-16 \mathrm{~V}, \mathrm{Q} 3=-20 \mathrm{~V}$ e modo negativo (ESI-), voltagem do capilar $=-30 \mathrm{~V} ; \mathrm{Q} 0=1,6 \mathrm{~V} ; \mathrm{Q} 1$ $=1,1 \mathrm{~V} ; \mathrm{Q} 2=16 \mathrm{~V}, \mathrm{Q} 3=20 \mathrm{~V}$.

As análises voltamétricas foram realizadas em um potenciostato Micro AutoLab III acoplado a um computador, com sistema de três eletrodos sendo o eletrodo de trabalho constituído de carbono vítreo $(3 \mathrm{~mm} \varnothing)$, o eletrodo auxiliar de fio de platina e o eletrodo de referência de $\mathrm{Ag} / \mathrm{AgCl}$. Para estas análises foi utilizado tampão fosfato como eletrólito suporte $(5,0 \mathrm{~mL} ; 50 \mathrm{mM} ; \mathrm{pH} 7,3)$ e adicionado volume apropriado de solução padrão de MDMA para se obter concentrações da ordem de $10^{-}$ ${ }^{4} \mathrm{~mol} \mathrm{~L}^{-1}$. As análises foram todas procedidas por etapa de desaeração com gás de nitrogênio durante 10 minutos.

Todas as varreduras voltamétricas foram realizadas em duplicatas. Para os gráficos montados a partir dos voltamogramas, os valores utilizados são referentes à média aritmética dos valores obtidos para cada duplicata.

\section{III.3 - Preparo das amostras}

Para a etapa cromatográfica, as amostras de ecstasy foram solubilizadas em metanol, sendo posteriormente centrifugadas e o sobrenadante foi retirado e injetado no sistema cromatográfico. Após a separação por CLAE, a solução obtida contendo metanol, água, acetato de amônio e MDMA foi rotaevaporada para retirar metanol e acetato de amônio e em seguida o MDMA foi extraído da solução aquosa utilizando acetato de etila por utilização de um funil de separação. Após ser separada da fase aquosa, a fase orgânica foi rotaevaporada e o óleo obtido foi utilizado para preparar as soluções padrão de MDMA por diluição em água. 
Para a etapa de determinação do teor de MDMA nas amostras de ecstasy, diferentes quantidades dos comprimidos da droga foram solubilizadas em 1,0 mL de água (tabela 2), centrifugadas e o sobrenadante foi retirado para ser utilizado no espectrômetro de massas (após ser diluído) e no sistema voltamétrico pela adição desta ao eletrólito suporte (100 $\mu \mathrm{L}$ da amostra dissolvida em água em 5,0 mL de eletrólito suporte). Foram construídas curvas analíticas utilizando soluções de concentrações conhecidas feitas a partir da solução padrão de MDMA comercial.

Tabela 2 - Quantidade de ecstasy solubilizado em 1,0 mL de água para cada amostra analisada.

\begin{tabular}{cc} 
Amostra & Quantidade (mg) \\
\hline E1 & 40,3 \\
E2 & 36,0 \\
E3 & 30,2 \\
E4 & 72,9 \\
E5 & 67,6 \\
\hline
\end{tabular}

\section{IV - RESULTADOS E DISCUSSÃO}

\section{IV.1 - Obtenção de soluções padrão de MDMA por CLAE}

Para que a MDMA pudesse ser analisada por voltametria, foi necessário isolar essa substância a partir de comprimidos de ecstasy obtidos em parceria com a Polícia Científica de Ribeirão Preto para criar as soluções padrão da mesma. Para tal, empregou-se o uso da Cromatografia Líquida de Alta Eficiência (CLAE), uma técnica eficiente quanto à separação dos componentes de uma mistura.

O procedimento foi realizado conforme descrito anteriormente e os cromatogramas obtidos da injeção das amostras no sistema foram comparados com o cromatograma obtido da injeção de solução padrão de MDMA nos quais se constatou a presença de um pico cromatográfico com tempo de retenção em 23 minutos, tempo similar ao do padrão (figuras 10 e 11). 


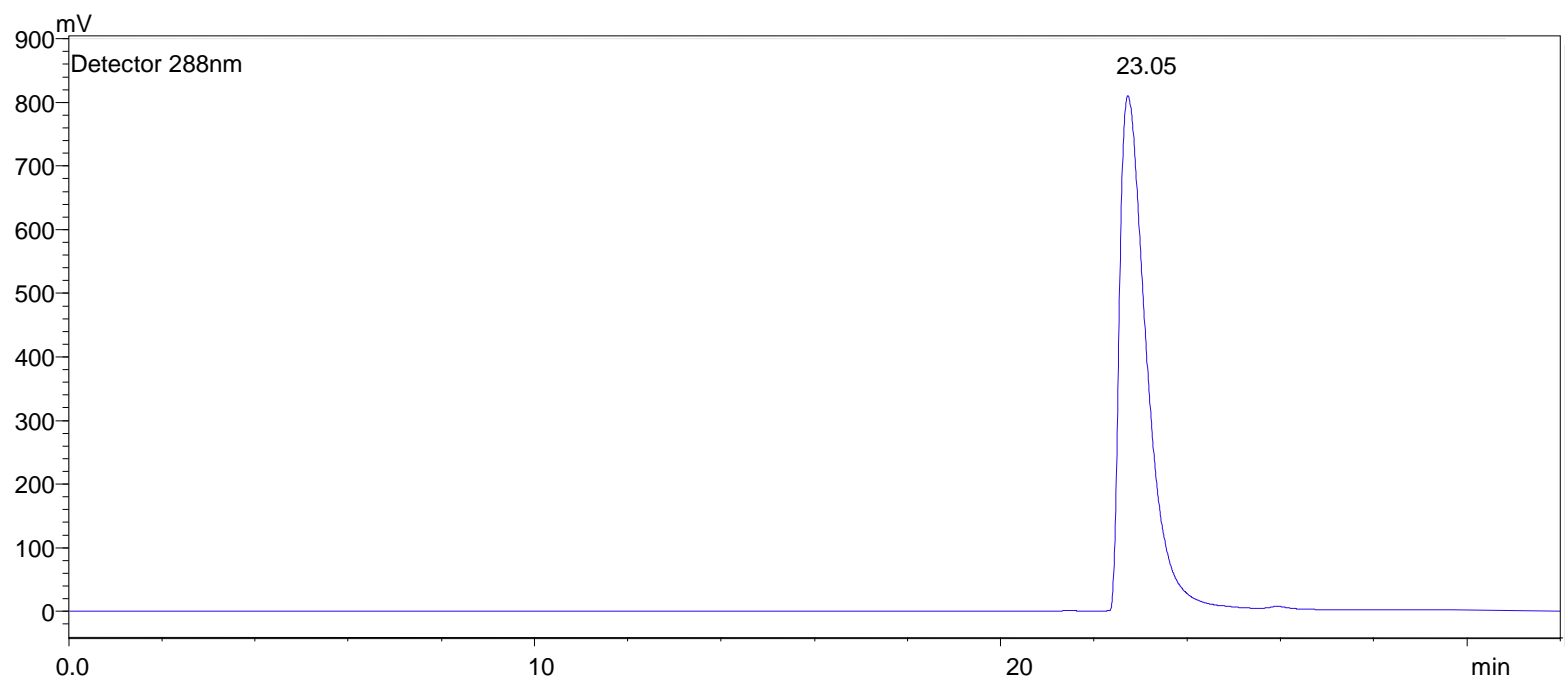

Figura 10 - Cromatograma da amostra de ecstasy exibindo pico com tempo de retenção em 23,05 minutos.

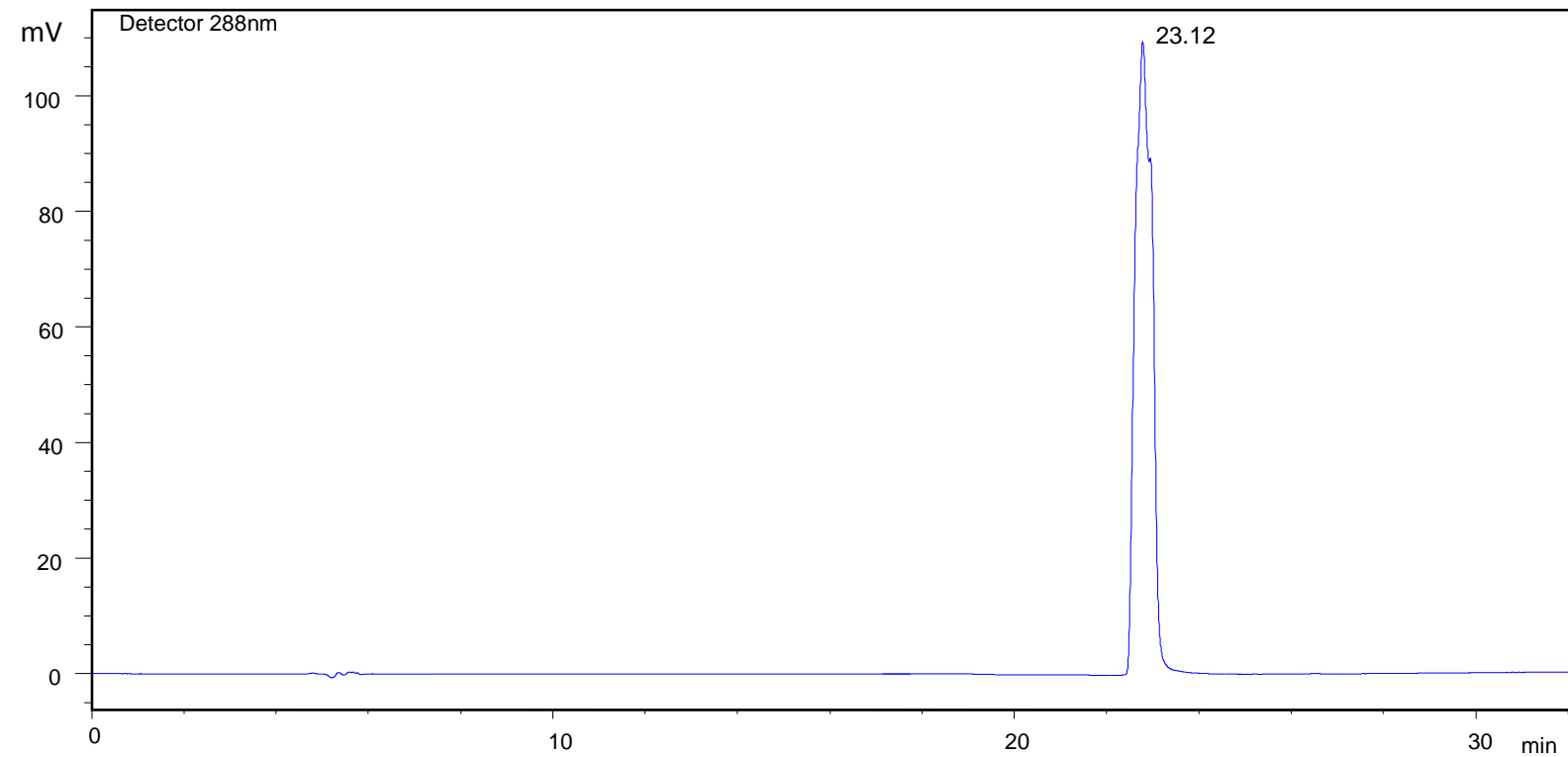

Figura 11 - Cromatograma da solução padrão de MDMA exibindo pico com tempo de retenção em 23,12 minutos.

Para confirmar a presença da MDMA, as amostras de ecstasy e a solução padrão de MDMA foram submetidas à espectrometria de massas, a qual exibiu o pico íon molecular de 194,200 que se refere à massa molar da MDMA de 193,2 g.mol ${ }^{-1}$ somada à massa molecular de um próton proveniente da ionização por electrospray, confirmando a presença da MDMA nas amostras de ecstasy (figura 12). Os picos 
menores que podem ser observados são impurezas presentes no equipamento ou na solução.

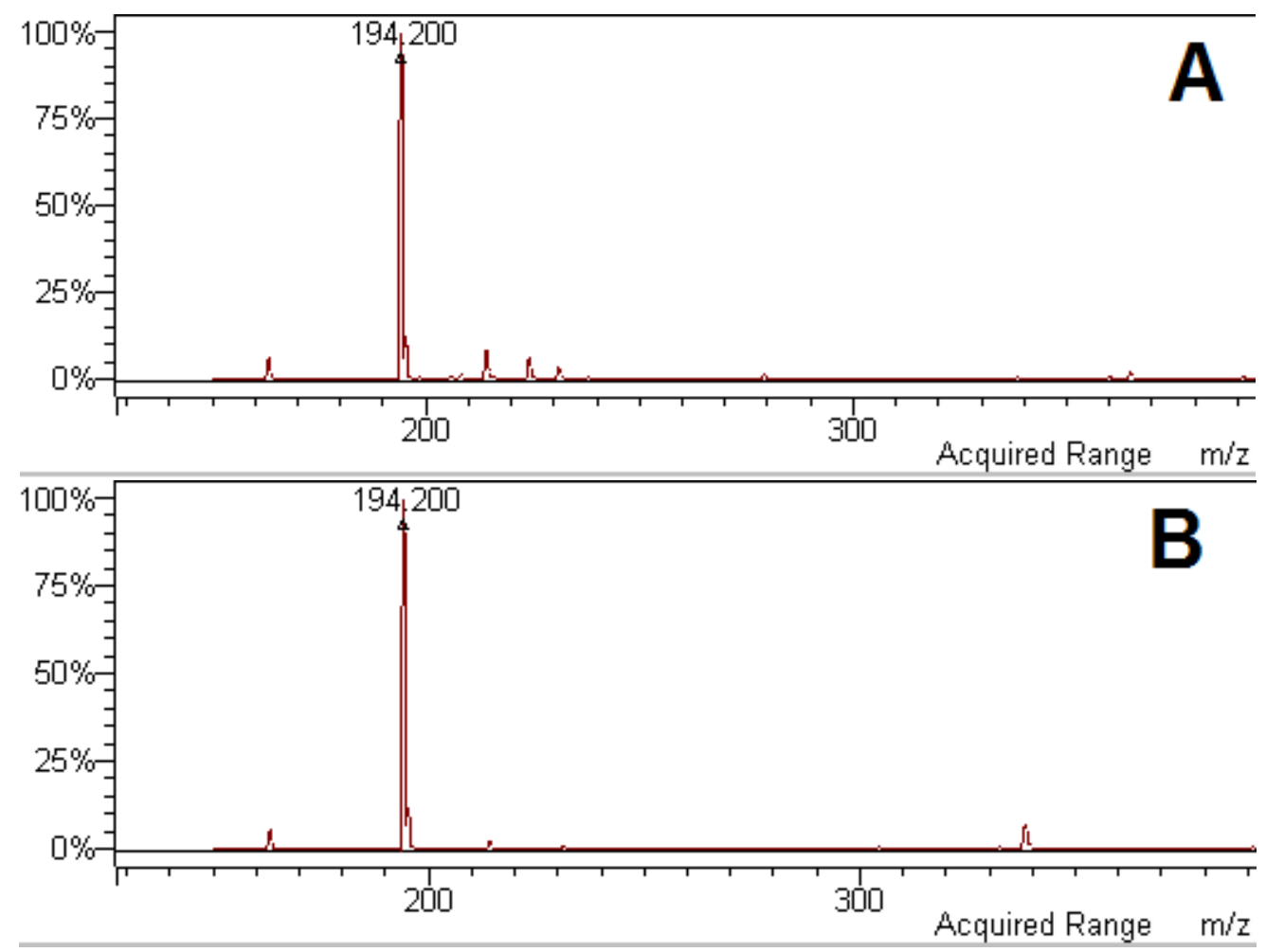

Figura 12 - Espectros de massas das amostras de ecstasy (A) e da solução padrão de MDMA (B).

A etapa preparativa da CLAE foi realizada para que pudesse ser obtido MDMA em grande quantidade a fim de se preparar soluções padrão com elevado grau de pureza. O pico cromatográfico na etapa preparativa mostra-se mais alargado e com tempo de retenção diferente da etapa analítica (figura 13), isso se deve ao fato de ser introduzida na coluna uma grande quantidade de analito, além da alta vazão utilizada $(0,6 \mathrm{~mL} / \mathrm{min}$ na etapa analítica e $11,3 \mathrm{~mL} / \mathrm{min}$ na etapa preparativa).

Após a solução padrão de MDMA obtida por CLAE ter sido preparada, uma alíquota desta foi submetida à espectrometria de massas, exibindo alto grau de pureza (figura 14), tornando a solução apropriada para os estudos voltamétricos. 


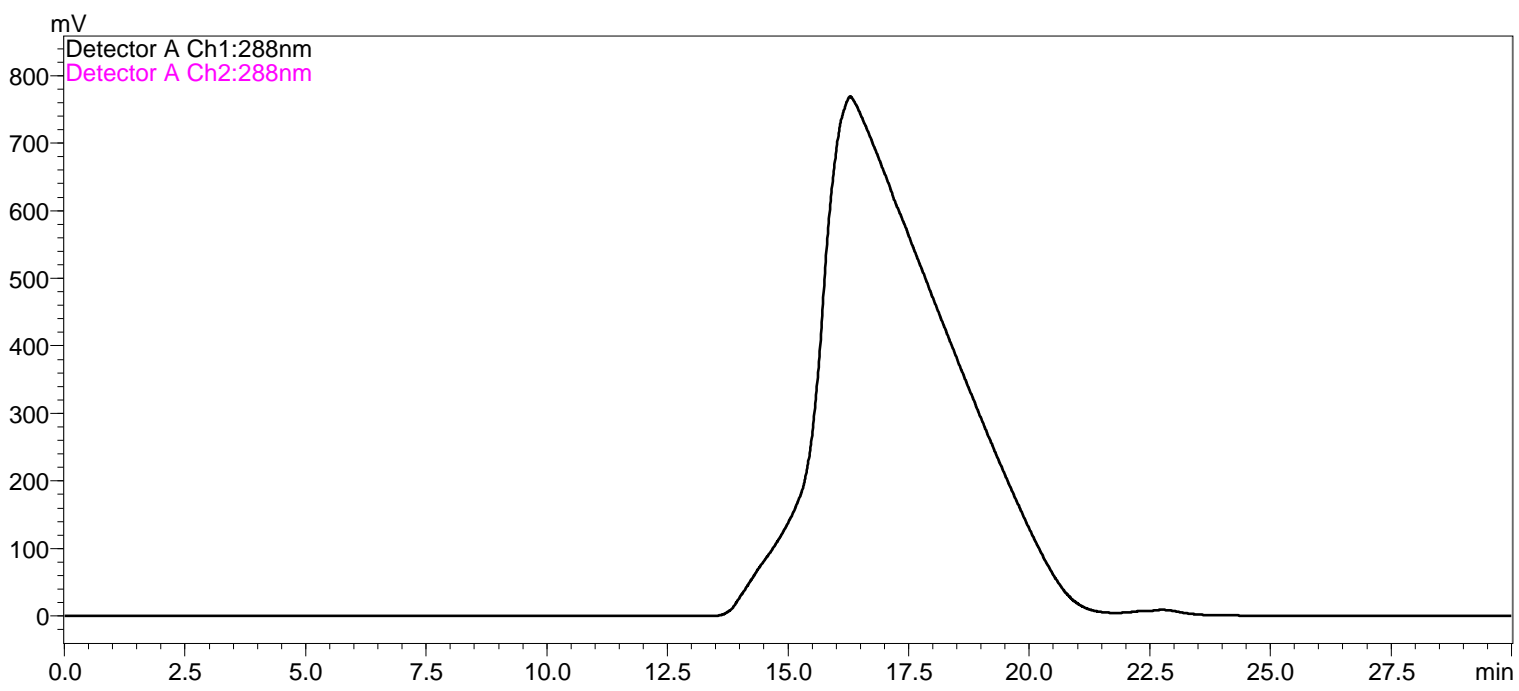

Figura 13 - Cromatograma da etapa preparativa da amostra de ecstasy.

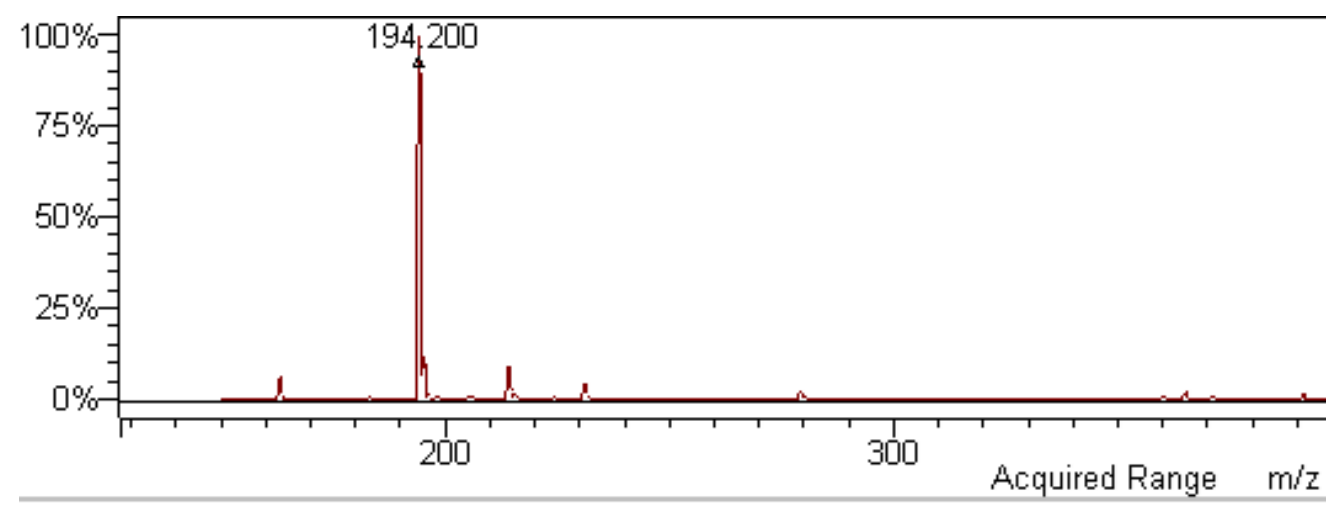

Figura 14 - Espectro de massas da solução padrão de MDMA obtida por CLAE. 


\section{IV.2 - Análises voltamétricas}

\section{IV.2.1 - Voltametria cíclica}

A 3,4-metilenodioximetanfetamina (MDMA) mostrou-se eletroativa na região de potencial anódico, desta forma, a faixa de trabalho escolhida para o potencial foi de $0 \mathrm{a}+1,6 \mathrm{~V}$. Através da voltametria cíclica, pode-se observar um pico anódico em $E_{p}=$ $+1,1 \mathrm{~V}$ e em concentrações mais baixas ou em velocidades de varredura muito rápidas, um segundo pico voltamétrico pôde ser observado em $E_{p}=+1,4$ V. GARRIDO ${ }^{[42] ~ e m ~}$ seus estudos relaciona o primeiro pico voltamétrico neste potencial à oxidação do núcleo aromático da molécula, levando à formação de um cátion radical e o segundo pico voltamétrico à dimerização do radical formado (esquema 1), sendo por esta razão que só pôde ser observado em concentrações baixas ou velocidades de varredura altas, pois o radical formado ainda estará nas proximidades da superfície do eletrodo de trabalho nessas condições. Como pode se observar no voltamograma (figura 15), este processo de oxidação da molécula não apresentou reversibilidade na transferência eletrônica nas condições experimentais utilizadas.

$$
\begin{aligned}
& \mathrm{ArCH}_{3} \rightleftharpoons \mathrm{ArCH}_{3}{ }^{++}+\left[\mathrm{e}^{-}\right] \quad \text { Pico } 1 \\
& 2 \mathrm{ArCH}_{3}{ }^{\cdot+} \rightarrow \mathrm{H} 3 \mathrm{CAr}-\mathrm{ArCH} 3 \\
& \mathrm{ArCH}_{3}{ }^{\bullet+} \rightleftharpoons \mathrm{ArCH}_{2}{ }^{\bullet}+\mathrm{H}^{+} \\
& \mathrm{ArCH}_{2}{ }^{-} \rightarrow\left[\mathrm{e}^{-}\right]+\mathrm{ArCH}_{2}{ }^{+} \text {, etc. }
\end{aligned}
$$

Esquema 1 - Mecanismo proposto por GARRIDO ${ }^{[42]}$ para a oxidação do núcleo aromático da molécula de MDMA e sua dimerização.

Observa-se pelo aumento da concentração do analito, um aumento na intensidade e definição do sinal analítico, exibindo comportamento linear na relação corrente de pico versus concentração de MDMA. 

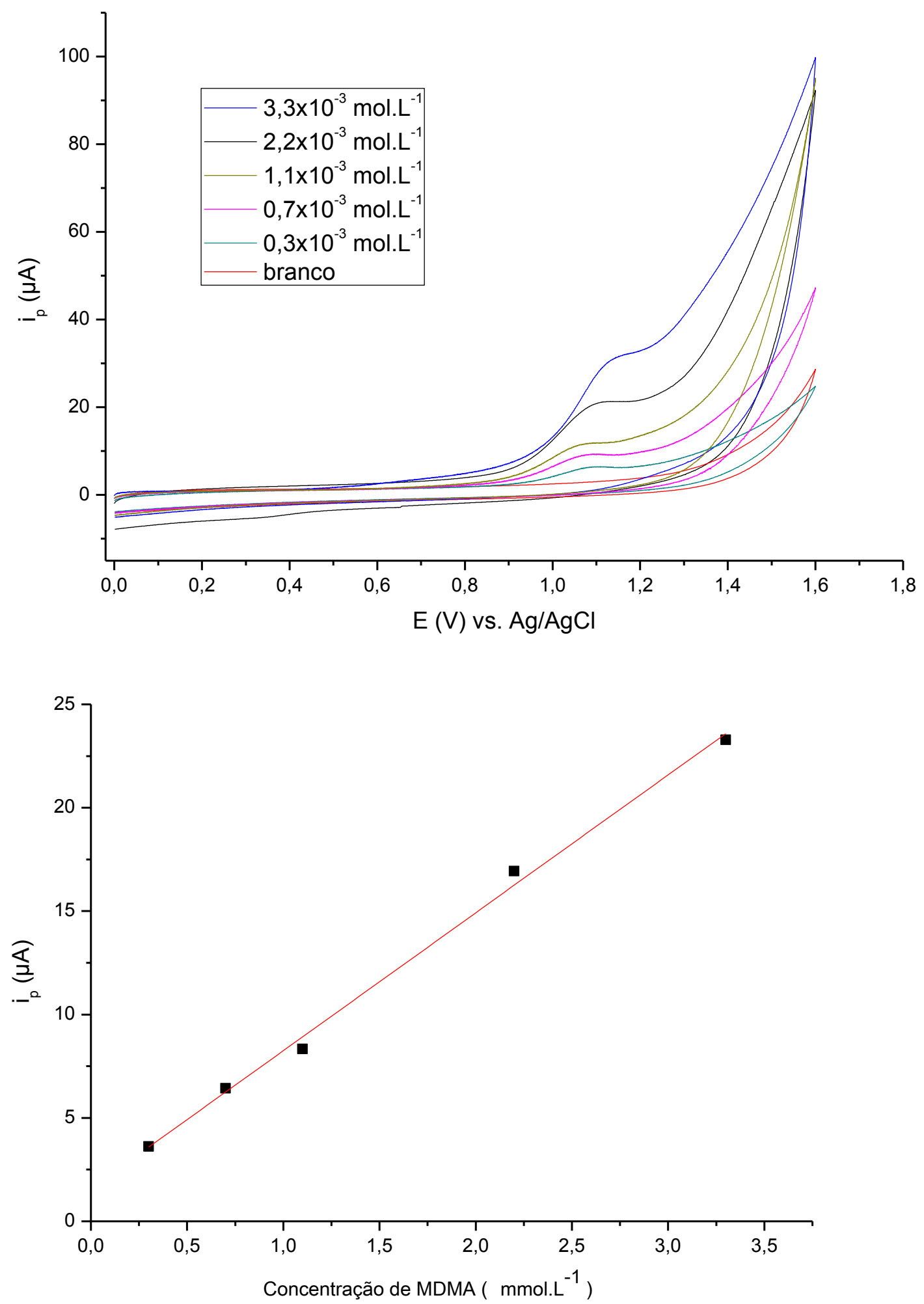

Figura 15 - Voltamograma cíclico da MDMA em diferentes concentrações e gráfico de corrente de pico versus concentração, exibindo comportamento linear. Eletrólito suporte tampão fosfato $25 \mathrm{mM}, \mathrm{pH} 7,3$; Velocidade de varredura $=200 \mathrm{mV} \cdot \mathrm{s}^{-1}$. 


\section{IV.2.2 - Voltametria de onda quadrada e voltametria de pulso diferencial}

Nas modalidades voltamétricas de onda quadrada e de pulso diferencial, é possível realizar uma etapa de pré-concentração anterior à análise. A etapa de préconcentração consiste em manter um potencial fixo no eletrodo no qual o analito não apresenta atividade eletroquímica, o que irá fazer com que ocorra atração das moléculas presentes na solução para a superfície do eletrodo de trabalho, aumentando a concentração do analito nas proximidades do eletrodo, levando ao aumento na intensidade do sinal observado. A realização da etapa de préconcentração torna a análise mais sensível sendo capaz de detectar o analito em concentrações mais baixas do que o limite de detecção da técnica sem a mesma.

Efetuou-se comparação entre análise voltamétrica direta e com 30 segundos de pré-concentração na mesma concentração do analito (figuras 16 e 17) e observouse que houve um aumento na intensidade e definição do pico voltamétrico. 

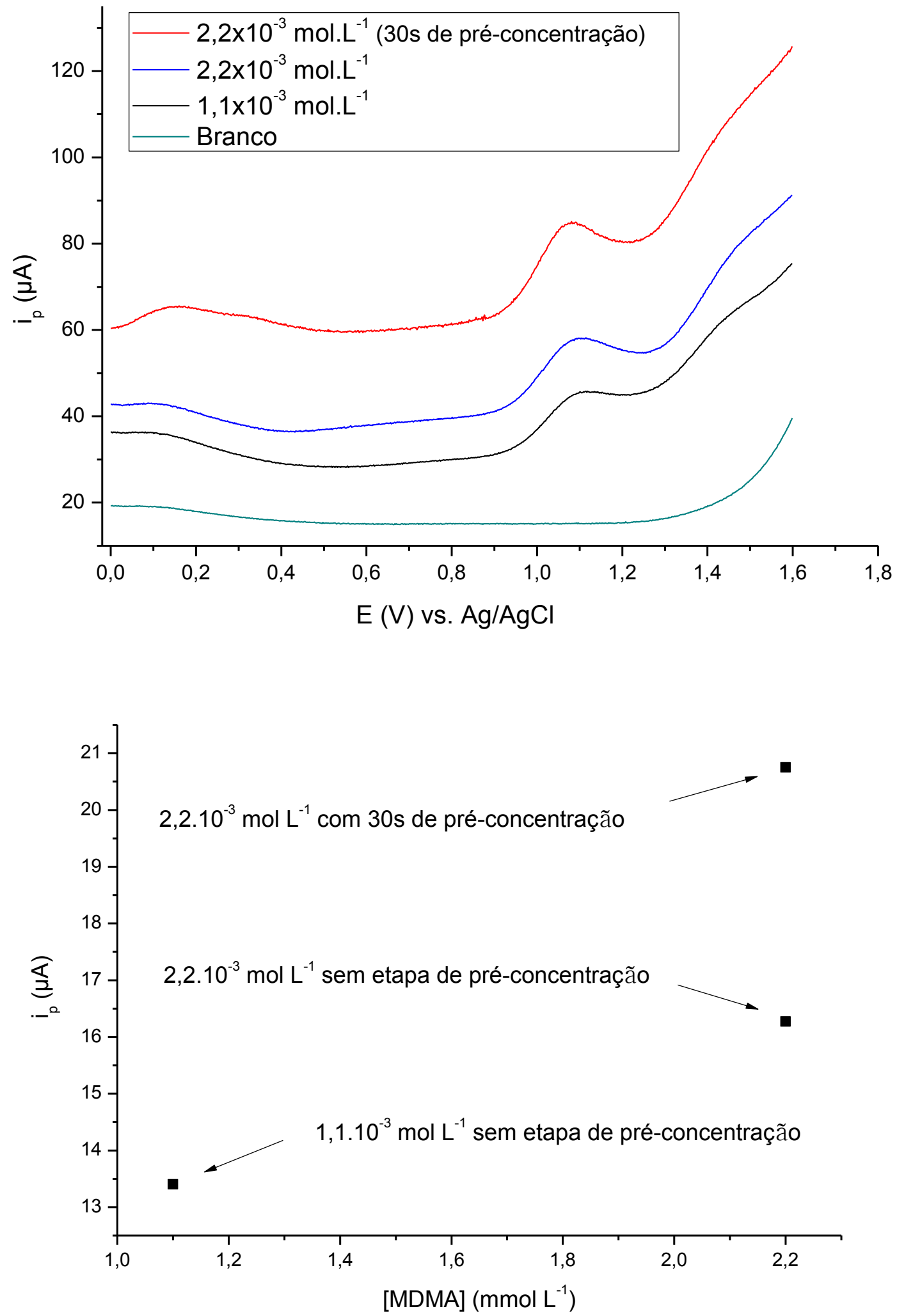

Figura 16 - Voltamograma de onda quadrada da MDMA em diferentes concentrações, com e sem etapa de pré-concentração e gráfico de corrente de pico versus concentração de MDMA. Eletrólito suporte tampão fosfato 25 mM, pH 7,3; Frequência = 100 Hz; Amplitude de onda = 49,95 mV. 

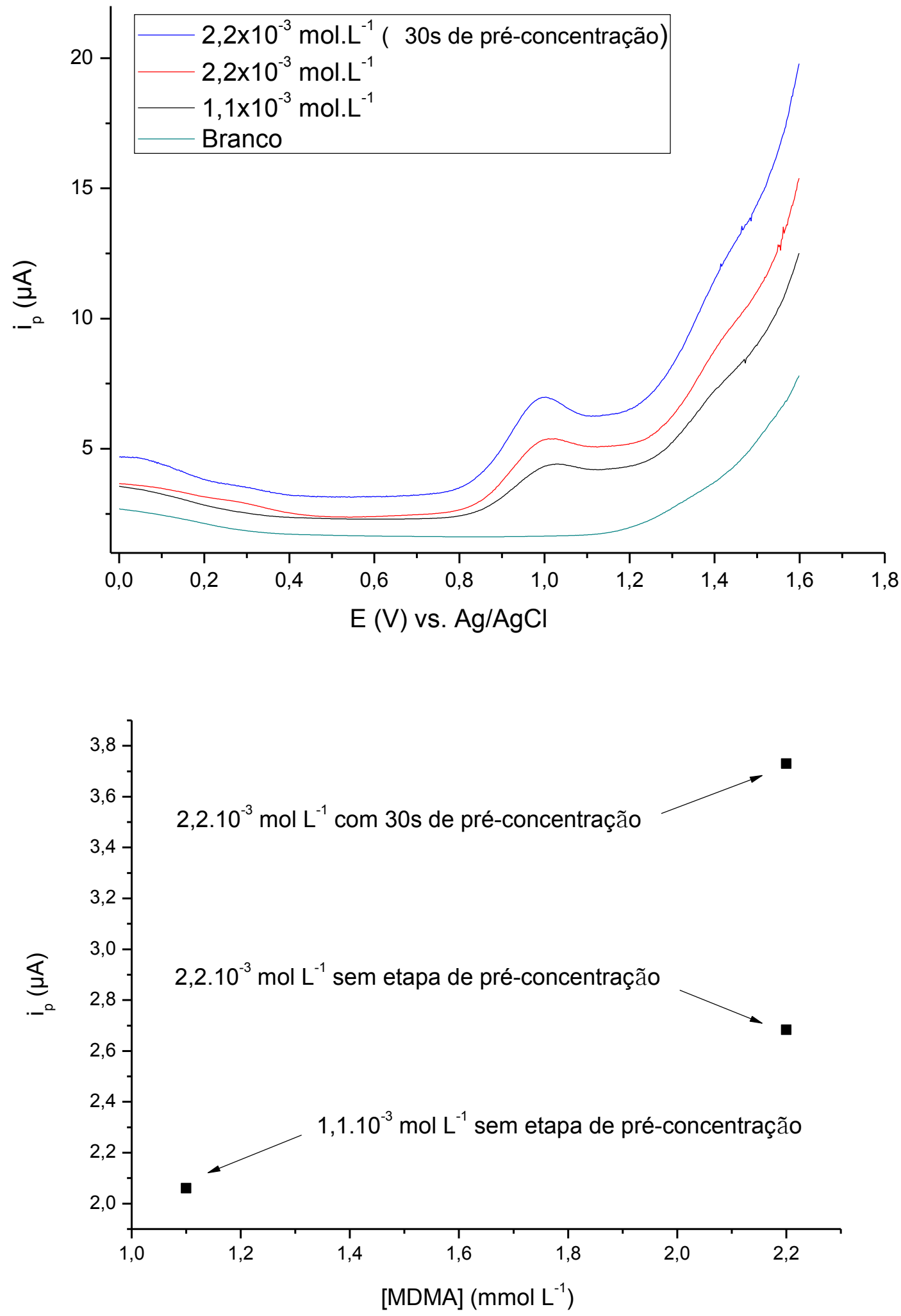

Figura 17 - Voltamograma de pulso diferencial da MDMA em diferentes concentrações, com e sem etapa de pré-concentração e gráfico de corrente de pico versus concentração de MDMA. Eletrólito suporte tampão fosfato $25 \mathrm{mM}$, pH 7,3; Intervalo de pulso = $500 \mathrm{~ms}$; Tempo de pulso = $50 \mathrm{~ms}$; Velocidade de varredura $=4 \mathrm{mV} \cdot \mathrm{s}^{-1}$. 


\section{IV.2.3 - Otimização dos parâmetros voltamétricos}

O tempo de uma análise voltamétrica depende de fatores como a velocidade de varredura, tempo de pré-concentração, entre outras e a modalidade voltamétrica escolhida, sendo a onda quadrada a mais rápida (poucos segundos) e pulso diferencial a mais demorada (poucos minutos), estando a voltametria cíclica em um tempo intermediário entre as anteriores (em torno de 30 segundos para um ciclo de varredura). Desta forma, para serem obtidos resultados mais rapidamente, estes parâmetros devem ser otimizados.

O valor ótimo para um parâmetro qualquer será aquele em que apresentar a maior intensidade na corrente elétrica medida no menor tempo, sem prejudicar a qualidade do sinal, gerando pouco ruído e alargamento da linha base.

\section{IV.2.3.1 - Otimização dos parâmetros voltamétricos - Voltametria cíclica}

Em voltametria cíclica, a velocidade de varredura escolhida deve ser rápida, mas que não comprometa a qualidade do sinal, gerando pouco ruído e pouco alargamento da linha base, de forma a produzir a maior corrente possível no menor tempo. Foram realizadas várias varreduras sob diferentes velocidades (figura 18) e as correntes de pico medidas foram plotadas contra as velocidades de varredura utilizadas (figura 19). Como o processo é controlado por difusão, utiliza-se a raiz quadrada da velocidade de varredura. A velocidade de varredura que apresentou maior corrente em menor intervalo de tempo foi de $300 \mathrm{mV} . \mathrm{s}^{-1}$, sendo portanto a mais adequada para os estudos voltamétricos. 


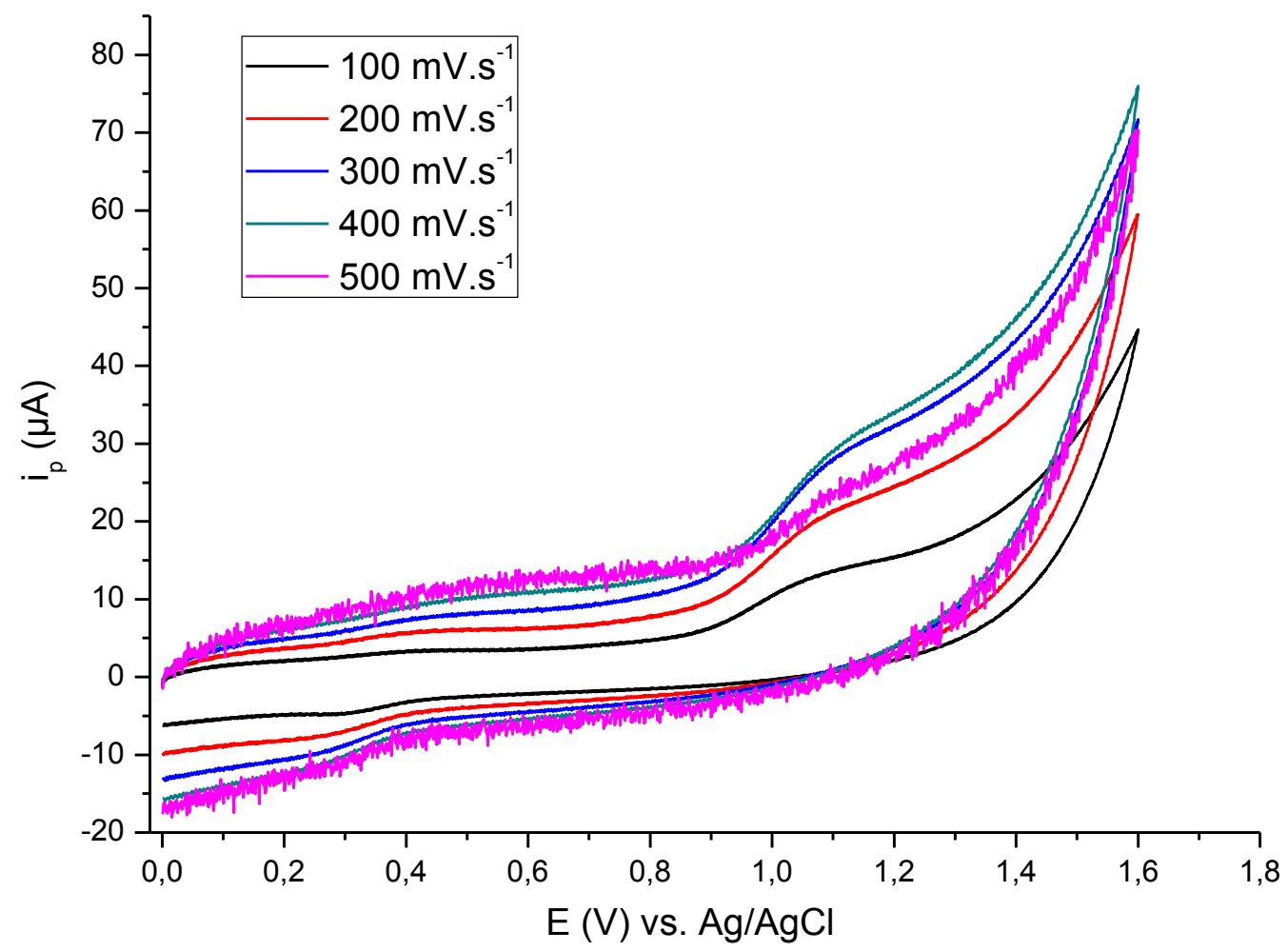

Figura 18 - Otimização do parâmetro velocidade de varredura em voltametria cíclica. Eletrólito suporte tampão fosfato $25 \mathrm{mM}, \mathrm{pH}$ 7,3; Concentração de MDMA = 3,3.10 $\mathrm{mol} \mathrm{L}^{-1}$.

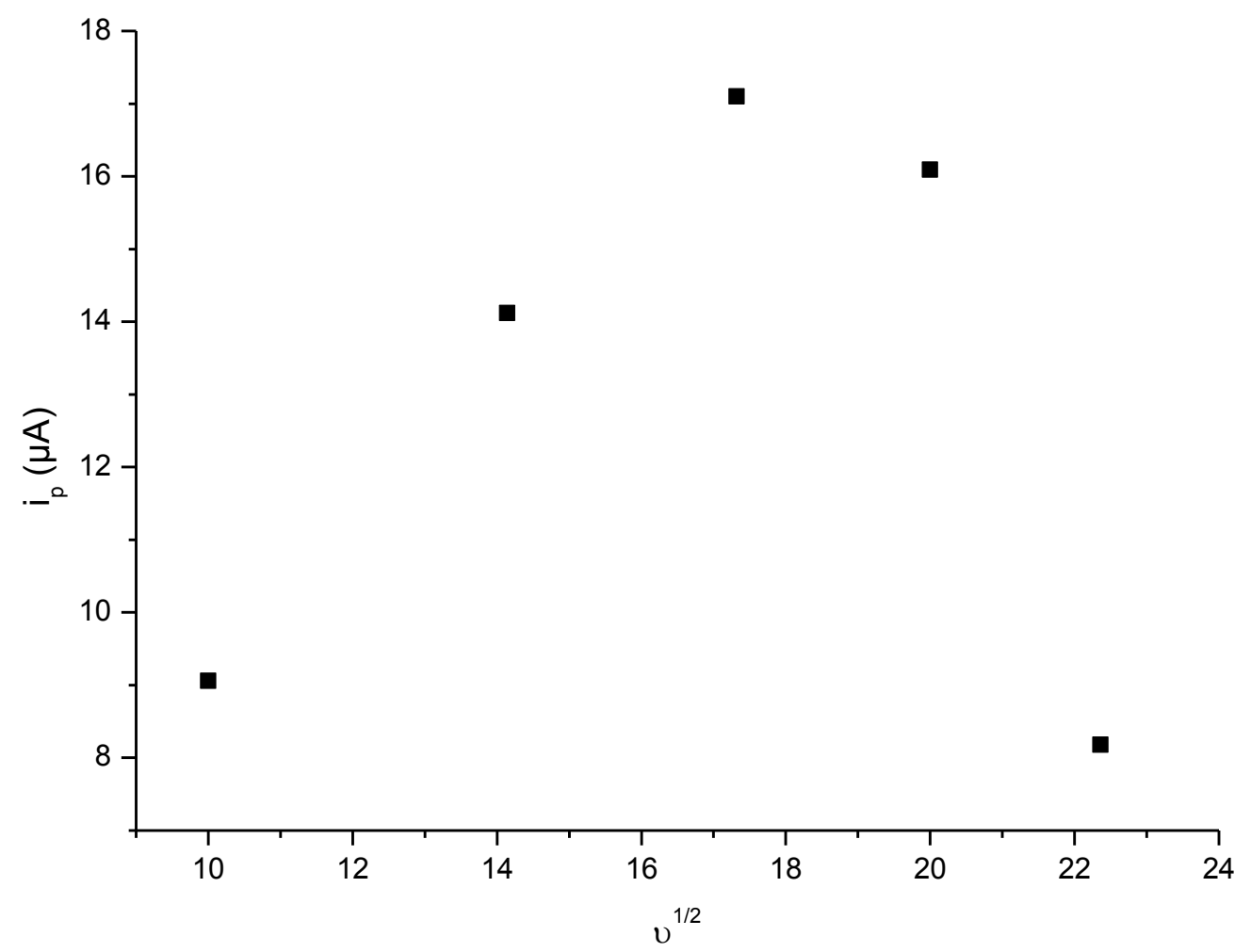

Figura 19 - Correntes de pico em voltametria cíclica plotadas contra as diferentes velocidades de varredura em que foram medidas. 
IV.2.3.2 - Otimização dos parâmetros voltamétricos - Voltametria de onda quadrada

Deve-se também otimizar os parâmetros que determinam a velocidade de varredura em voltametria de onda quadrada, que são a amplitude (figura 20) e a frequência de onda (figura 22). Observa-se que não há aumento significativo na corrente e no alargamento e ruído da linha base a partir da amplitude de onda de 49,95 mV (figura 21), sendo esta a amplitude utilizada como ideal. Para a frequência de onda, o valor ótimo obtido foi sob a frequência de $200 \mathrm{~Hz}$ (figura 23), sendo esta a frequência ideal para as análises. 


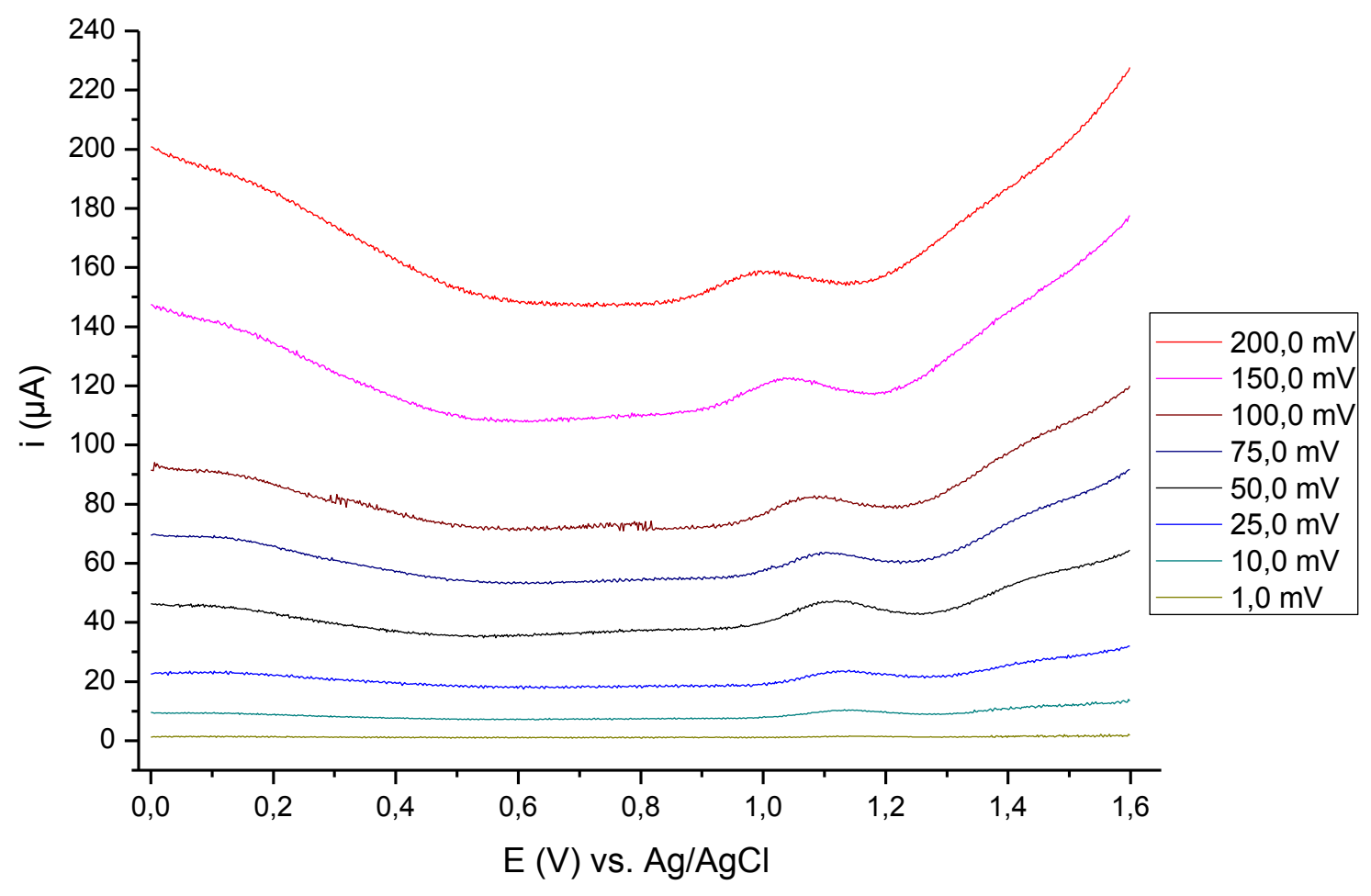

Figura 20 - Otimização do parâmetro amplitude de onda em voltametria de onda quadrada. Eletrólito

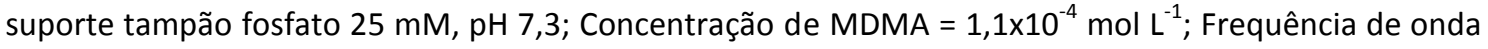
$=100 \mathrm{~Hz}$.

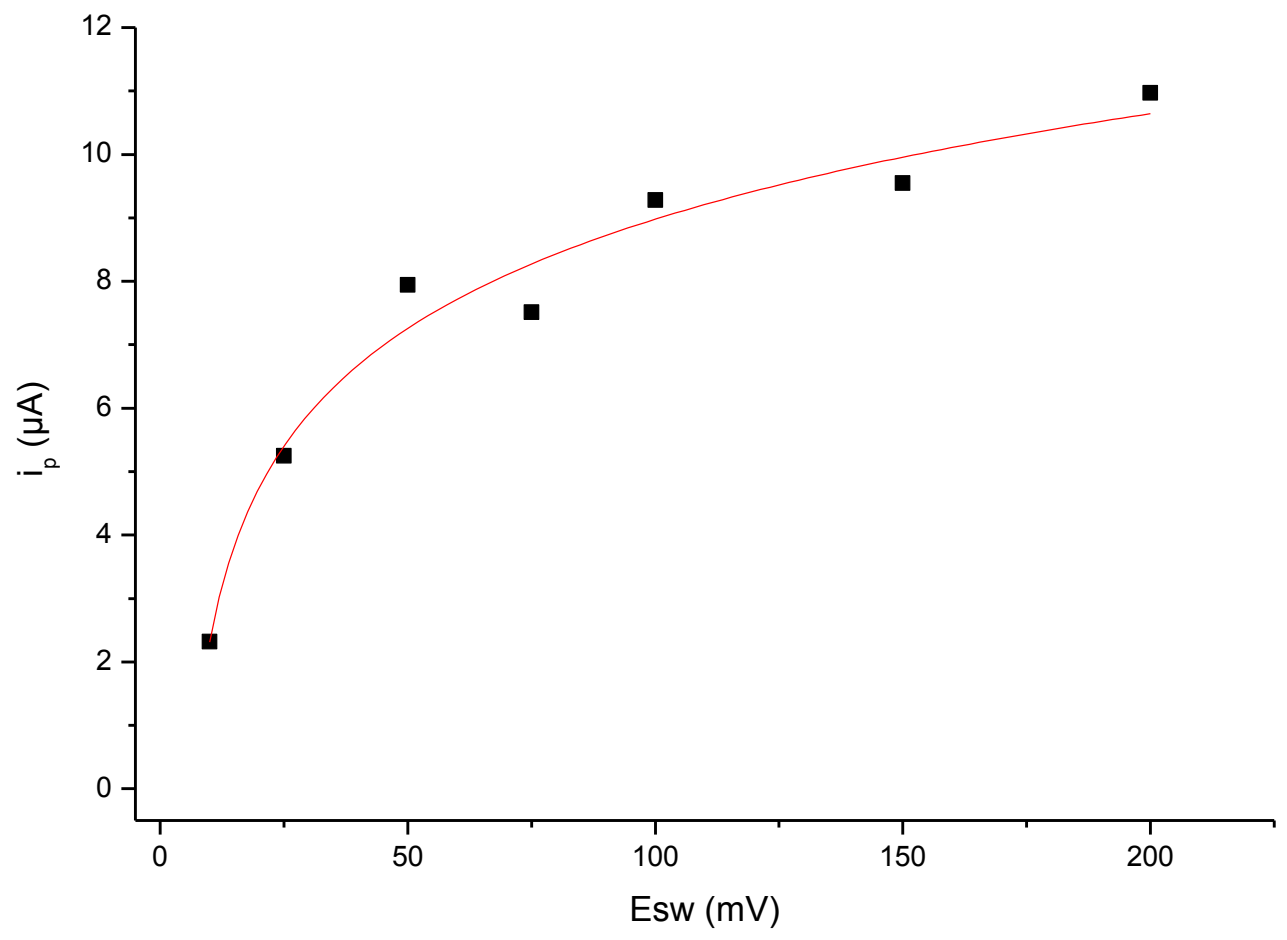

Figura 21 - Correntes medidas em voltametria de onda quadrada plotadas contra as diferentes amplitudes de onda testadas. 


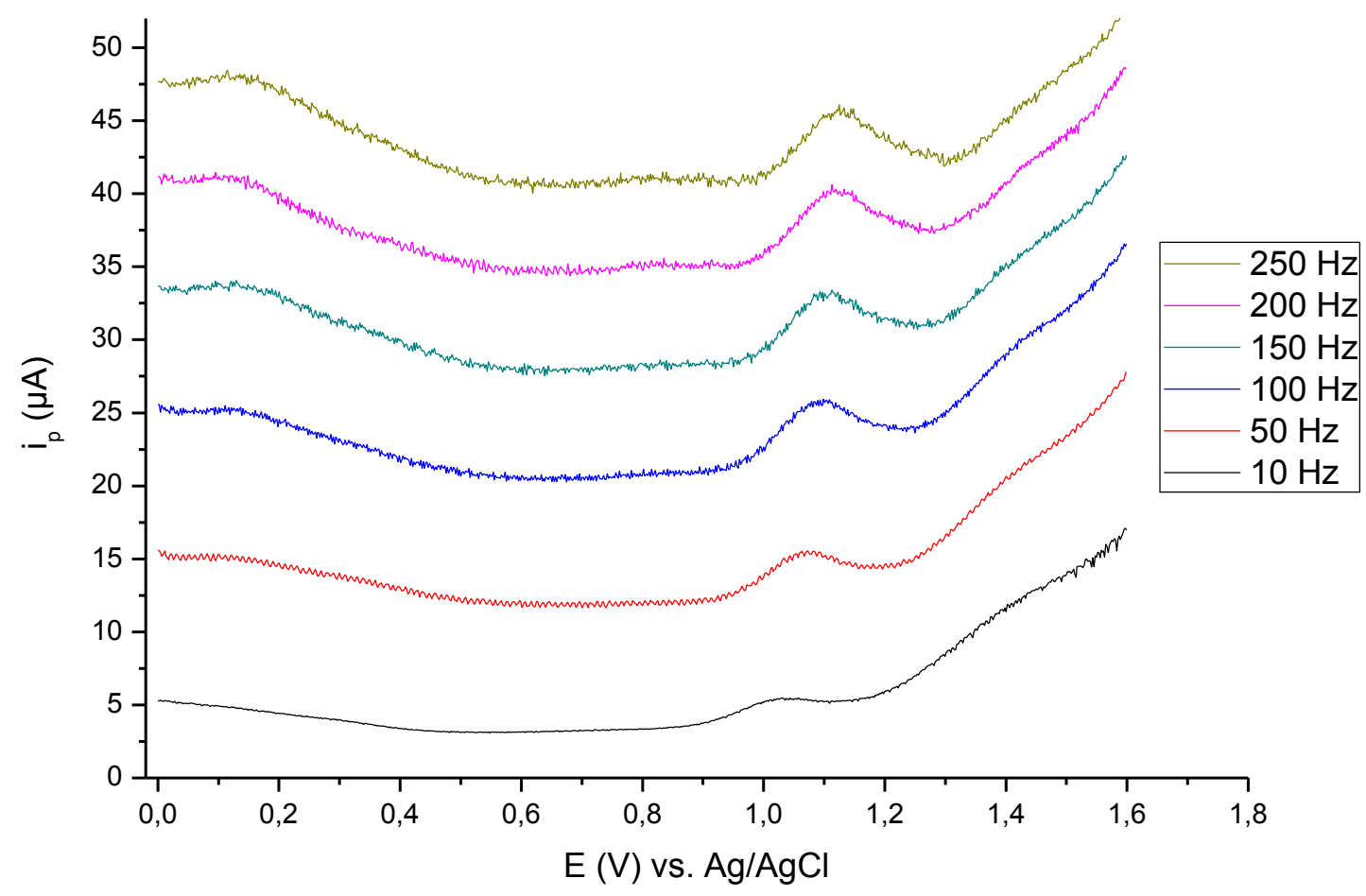

Figura 22 - Otimização do parâmetro frequência de onda em voltametria de onda quadrada. Eletrólito suporte tampão fosfato $25 \mathrm{mM}, \mathrm{pH} 7,3$; Concentração de MDMA = 1,1 $1 \times 10^{-4} \mathrm{~mol} \mathrm{~L}^{-1}$; Amplitude de onda = $49,95 \mathrm{mV}$.

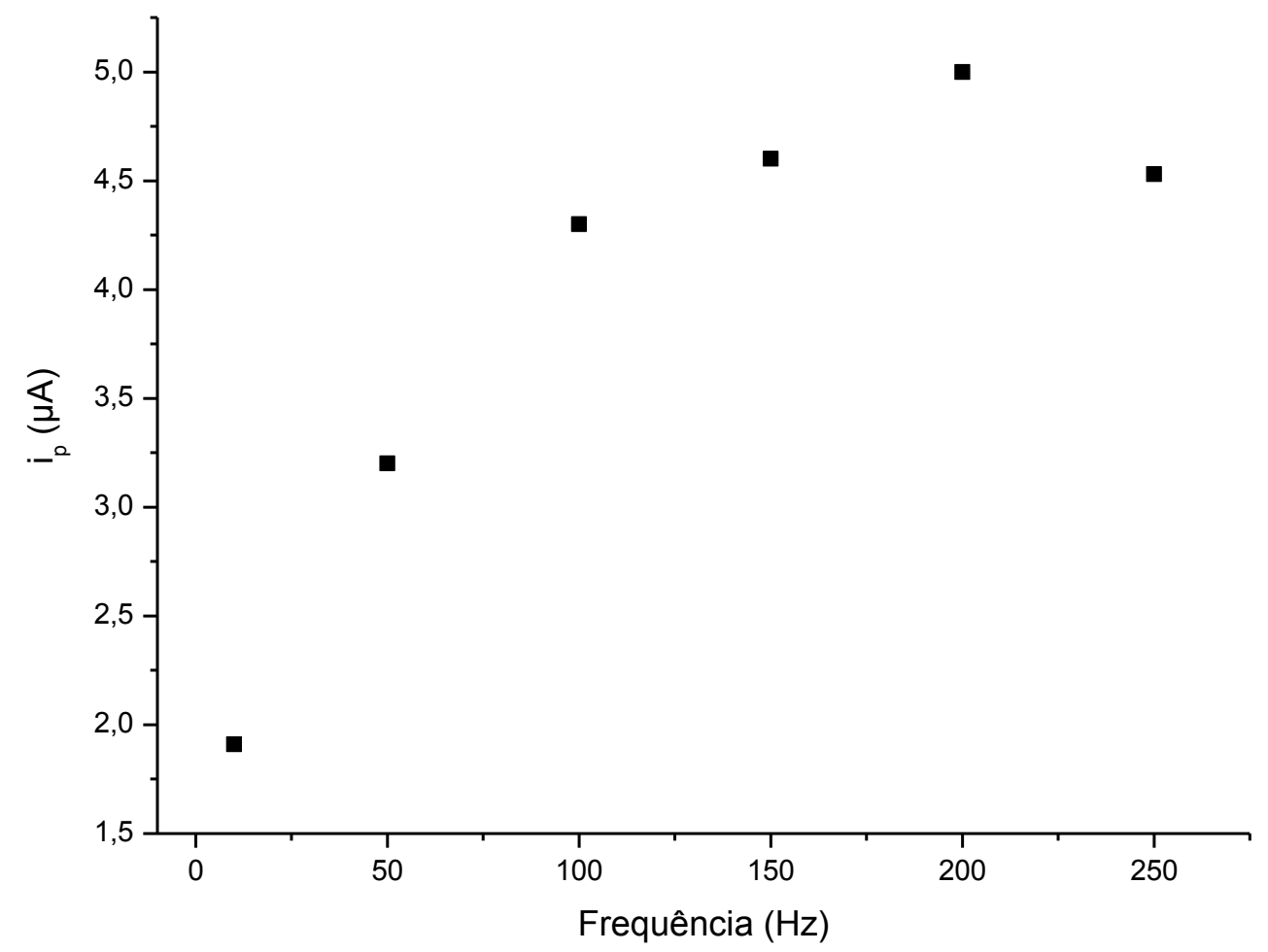

Figura 23 - Correntes medidas em voltametria de onda quadrada plotadas contra as diferentes frequências testadas. 
IV.2.3.3 - Otimização dos parâmetros voltamétricos - Voltametria de pulso diferencial

Os parâmetros otimizados em voltametria de pulso diferencial foram o intervalo de pulso, $\Delta E_{p}$ (figuras 24 e 25 ) e o tempo de pulso, $t_{p}$ (figuras 26 e 27). Os valores ideais obtidos para estes parâmetros foram respectivamente de $0,13 \mathrm{~V}$ e 50 ms, os quais tornam a análise mais rápida e sensível. 


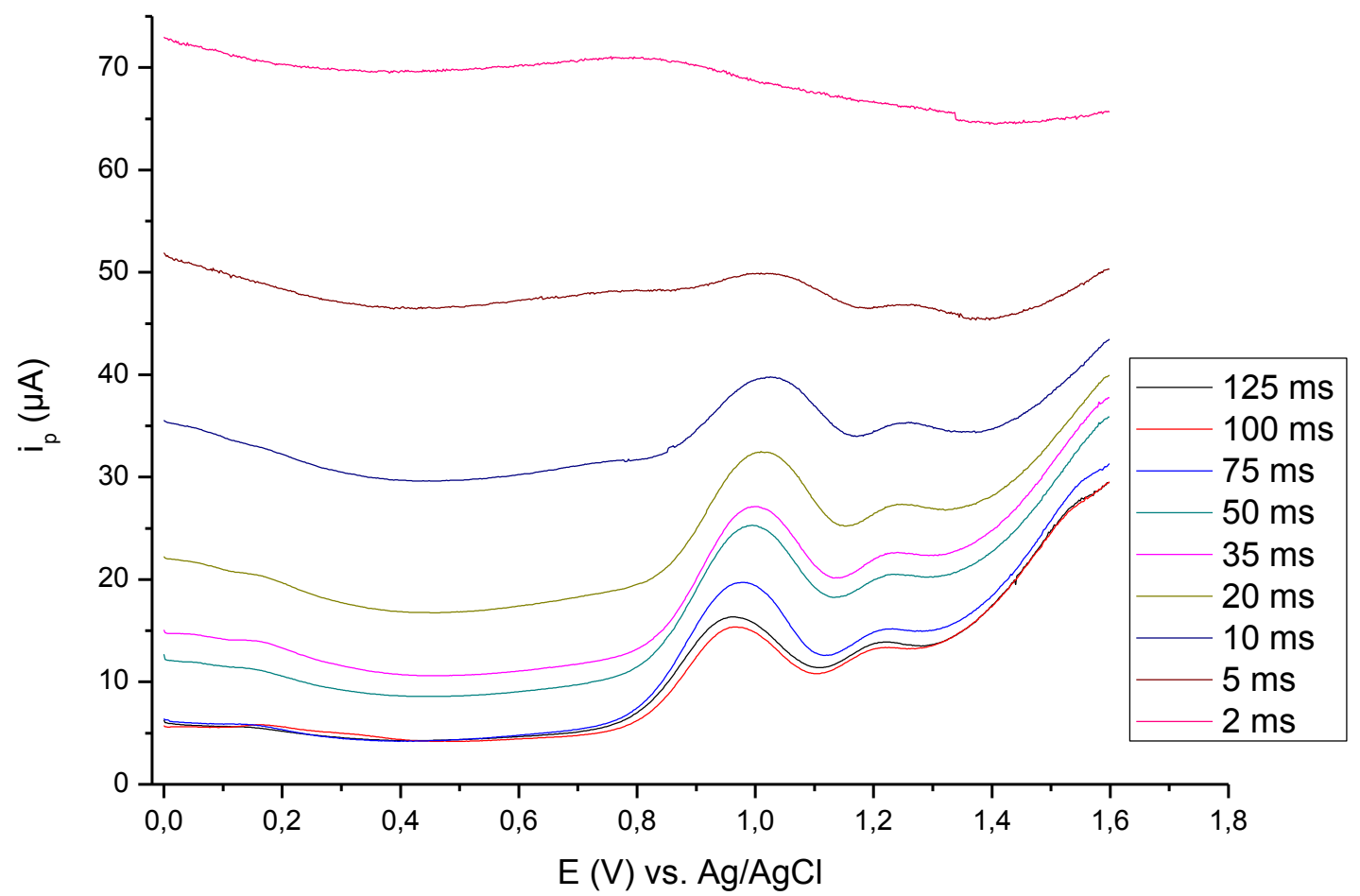

Figura 24 - Otimização do parâmetro tempo de pulso em voltametria de pulso diferencial. Eletrólito suporte tampão fosfato $25 \mathrm{mM}, \mathrm{pH} \mathrm{7,3}$; Concentração de MDMA $=1,1 \times 10^{-4} \mathrm{~mol} \mathrm{~L}^{-1} ; \Delta \mathrm{E}_{\mathrm{p}}=50 \mathrm{mV}$.

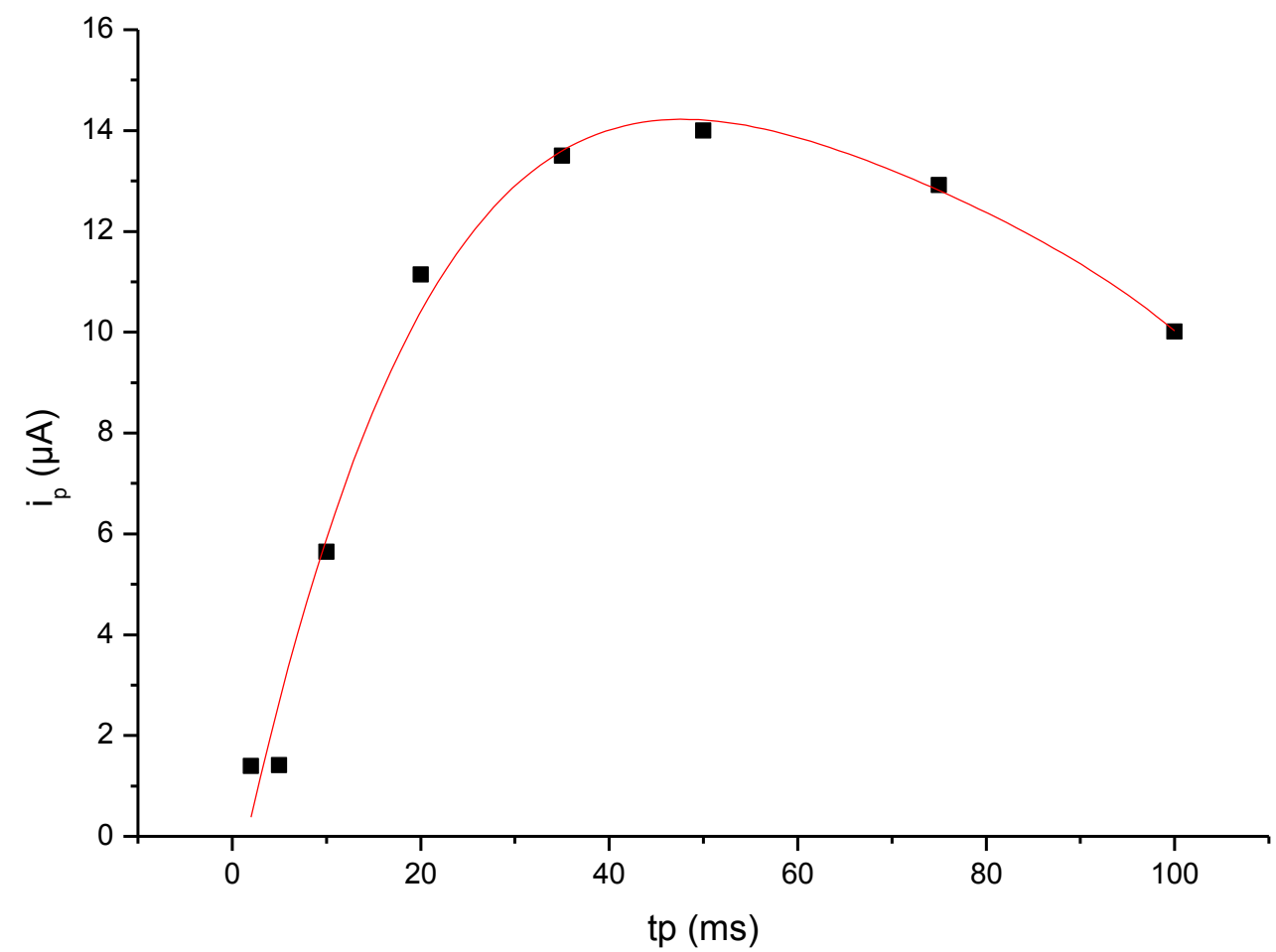

Figura 25 - Correntes medidas em voltametria de pulso diferencial plotadas contra os diferentes tempos de pulso testados. 


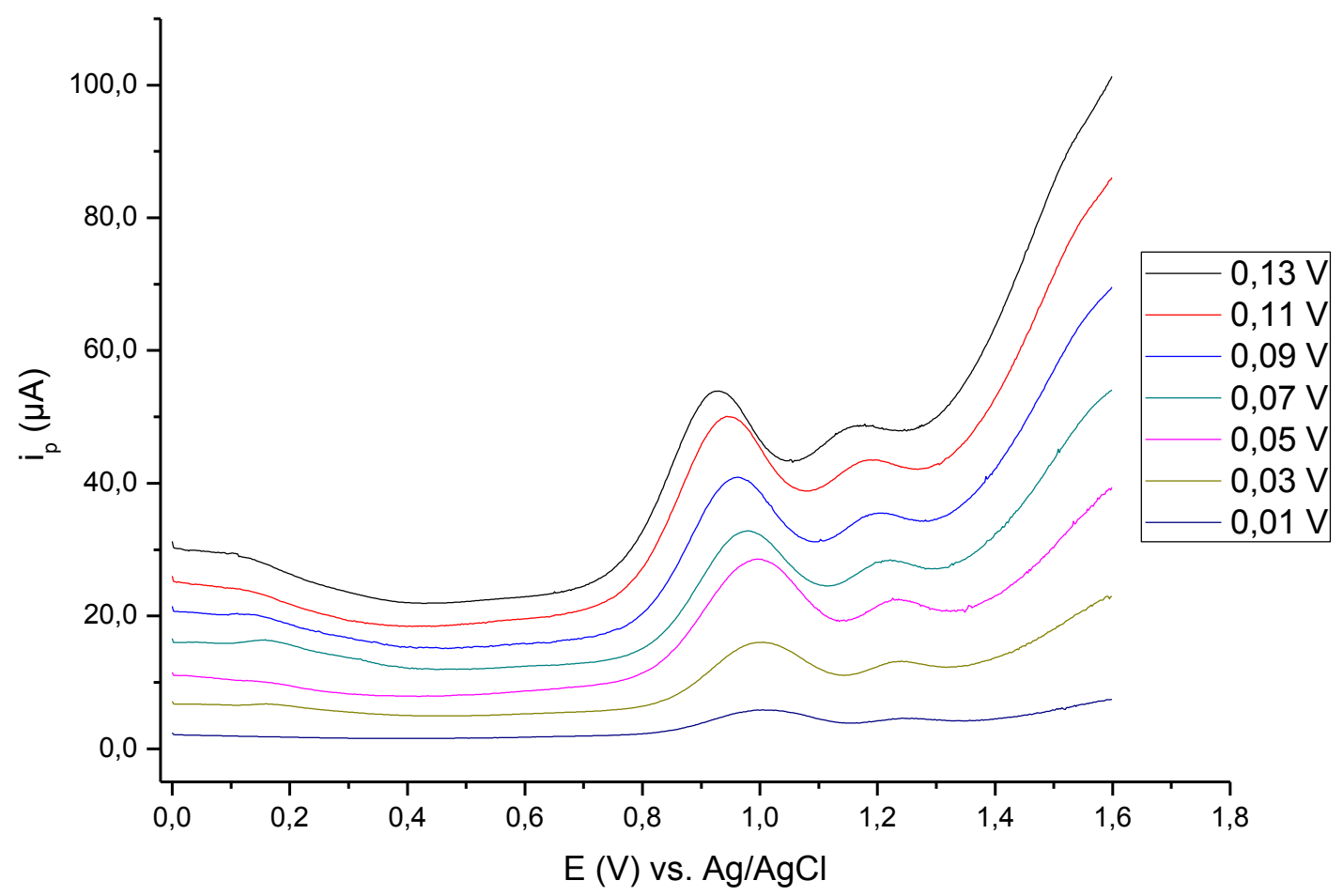

Figura 26 - Otimização do parâmetro intervalo de pulso em voltametria de pulso diferencial. Eletrólito suporte tampão fosfato $25 \mathrm{mM}, \mathrm{pH} 7,3$; Concentração de MDMA $=1,1 \times 10^{-4} \mathrm{~mol} \mathrm{~L}^{-1} ; \mathrm{t}_{\mathrm{p}}=50 \mathrm{~ms}$.

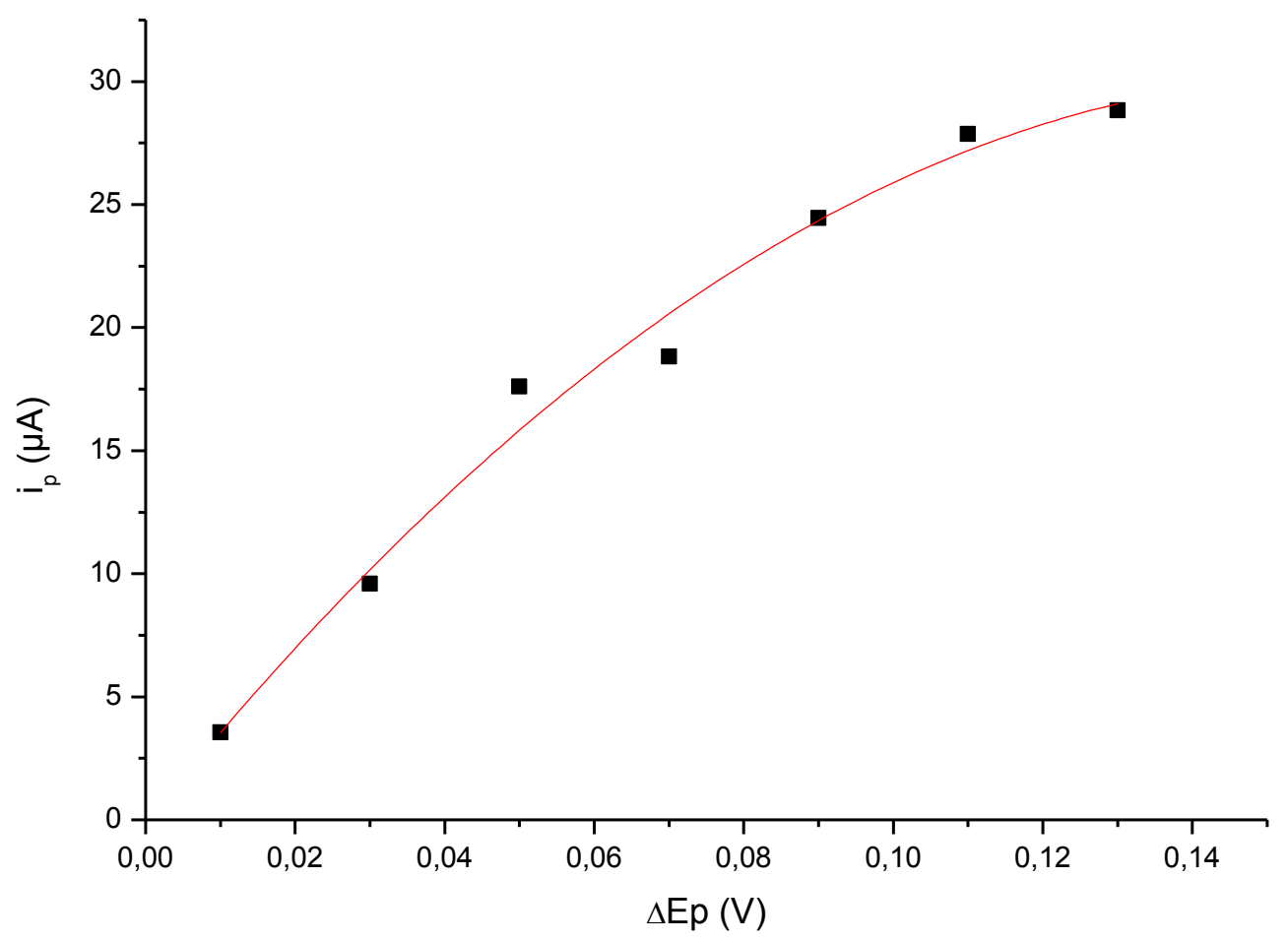

Figura 27 - Correntes medidas em voltametria de pulso diferencial plotadas contra os diferentes intervalos de pulso testados. 


\section{IV.2.3.4 - Otimização dos parâmetros voltamétricos - Etapa de pré- concentração}

Para se escolher o tempo de pré-concentração apropriado é necessário que se escolha inicialmente o potencial em que o processo ocorrerá. O melhor potencial a ser escolhido deve apresentar maior intensificação do sinal em um mesmo tempo de varredura sem comprometimento do sinal e intensificação do ruído. O potencial escolhido foi de $-1,0 \mathrm{~V}$ (figuras 28 e 29).

Com o potencial de pré-concentração otimizado, realizaram-se diversas varreduras utilizando diferentes tempos de pré-concentração buscando obter a melhor intensificação do sinal analítico sem prolongar demasiadamente o tempo de análise (figura 30). Observa-se pelo gráfico das correntes medidas contra os tempos de pré-concentração utilizados (figura 31) que a intensidade do sinal aumenta com o tempo de pré-concentração, no entanto, não há um aumento tão intenso a partir de 60 segundos, quanto nos tempos menores que este. Desta forma, pode-se utilizar esse tempo como o ideal para obter resultados de qualidade, intensificando o sinal voltamétrico sem prolongar a análise por tempo demasiado.

O tempo de pré-concentração, portanto, dependerá essencialmente da concentração do analito na solução. Se a concentração do analito for baixa, tempos de pré-concentração mais longos serão necessários e em concentrações mais altas, tempos menores ou até mesmo pode-se suprimir esta etapa da análise. 


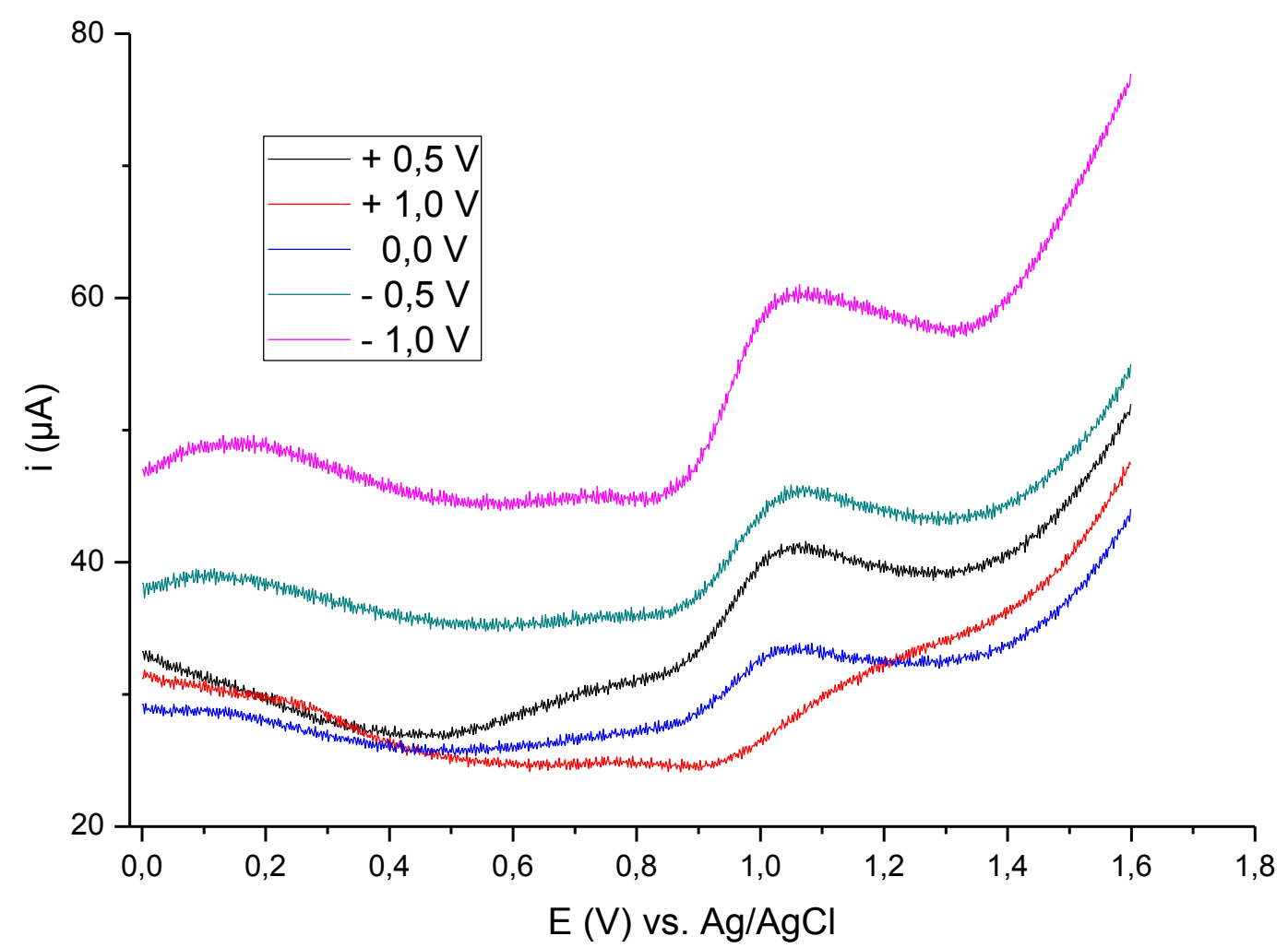

Figura 28 - Diferentes potenciais de pré-concentração testados em voltametria de onda quadrada. Tempo de pré-concentração $=20$ s; Amplitude de onda $=49.95 \mathrm{mV}$; Frequência $=100 \mathrm{~Hz}$; Concentração de $M D M A=2,2 \times 10^{-3} \mathrm{~mol} \mathrm{~L}^{-1}$; Eletrólito suporte tampão fosfato $25 \mathrm{mM}, \mathrm{pH} 7,3$.

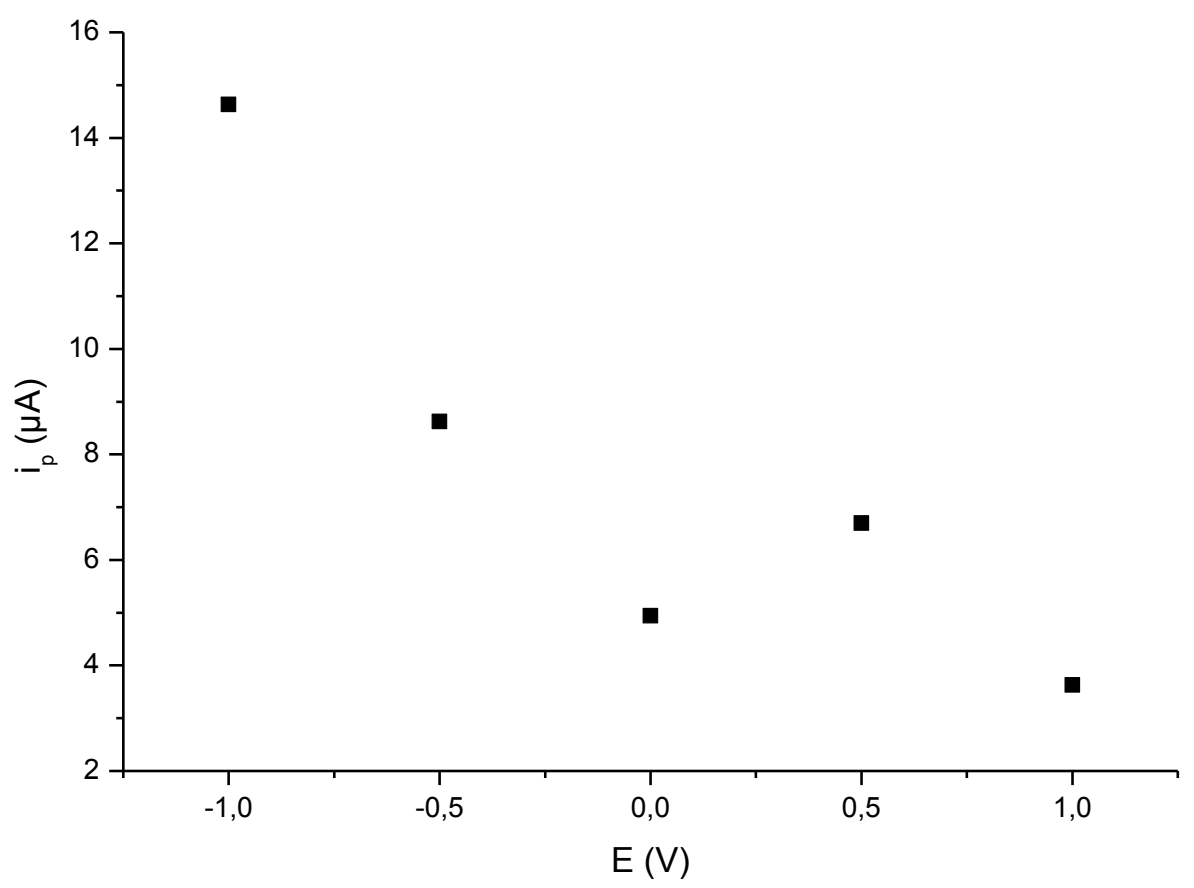

Figura 29 - Correntes de pico em voltametria de onda quadrada plotadas contra os diferentes potenciais testados na etapa de pré-concentração. 


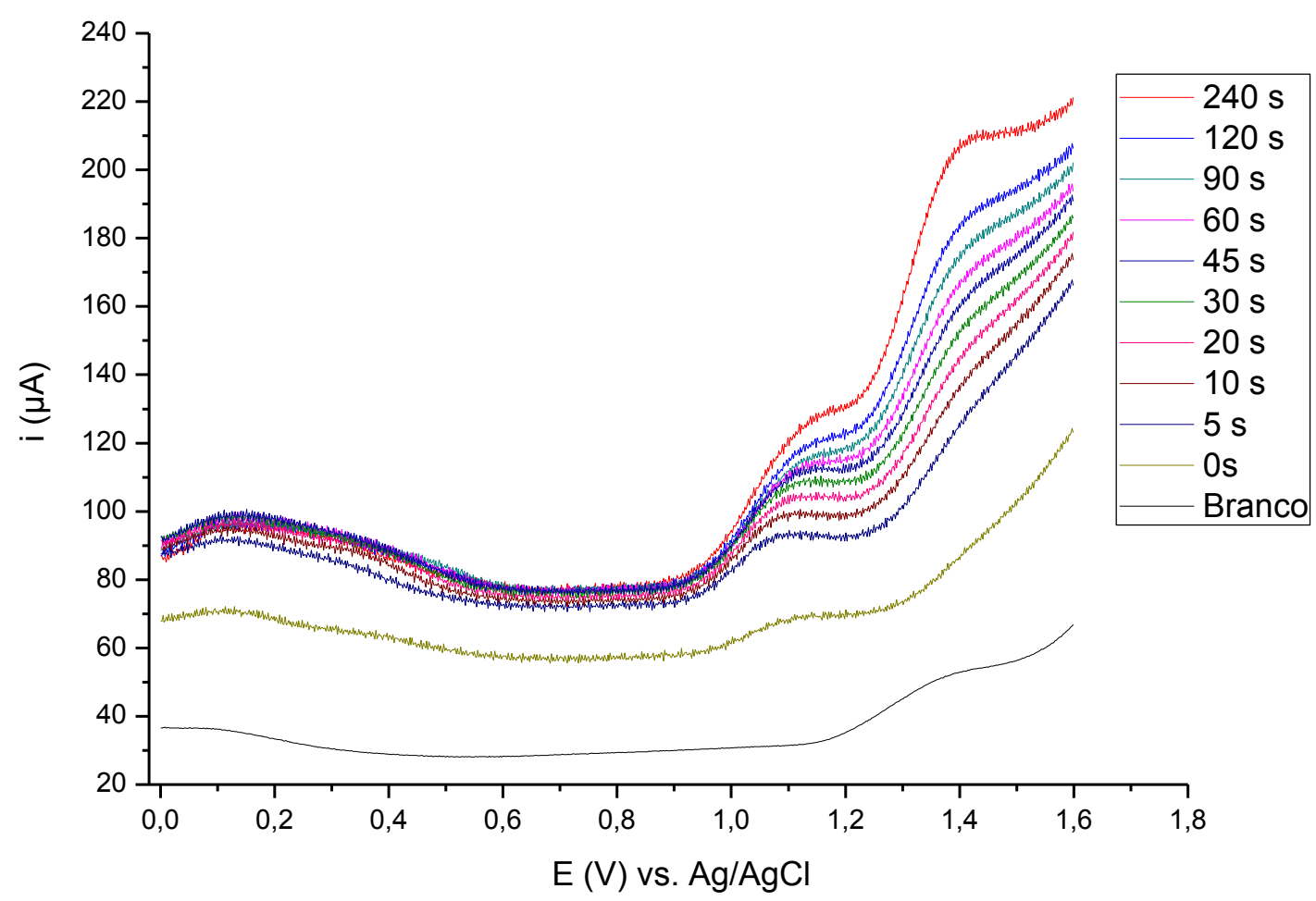

Figura 30 - Voltamogramas de onda quadrada exibindo diferentes tempos de pré-concentração. Concentração de MDMA $=2,2 \times 10^{-3} \mathrm{~mol} \mathrm{~L}^{-1}$; Amplitude de onda $=49.95 \mathrm{mV}$; Frequência $=100 \mathrm{~Hz}$; Potencial de pré-concentração = -1,0 V; Eletrólito suporte tampão fosfato 25 mM, pH 7,3.

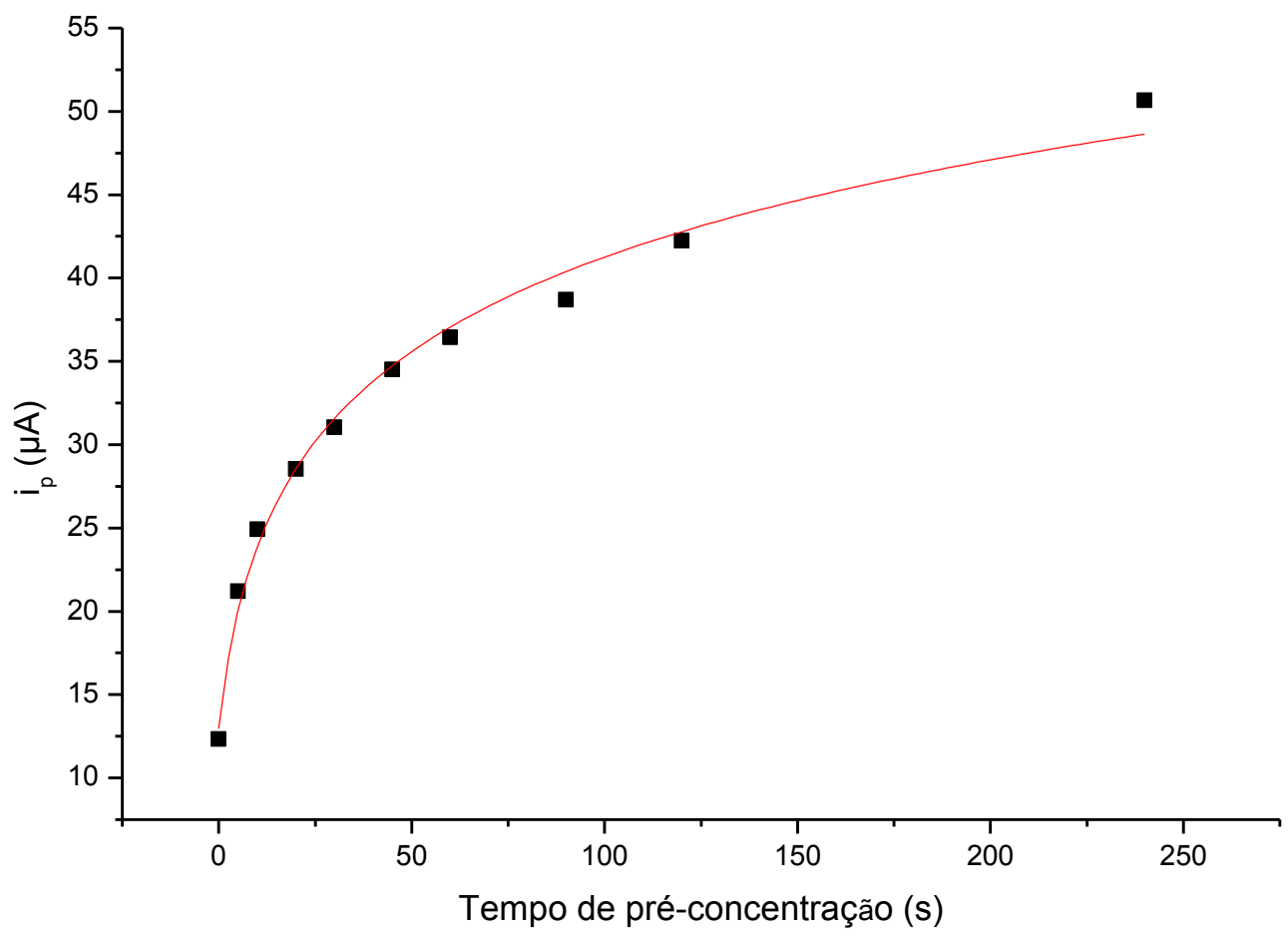

Figura 31 - Correntes de pico em voltametria de onda quadrada plotadas contra os diferentes tempos de pré-concentração em que foram medidas. 


\section{IV.3 - Determinação do intervalo de trabalho e limites de detecção}

Com os parâmetros voltamétricos otimizados, o intervalo de trabalho das curvas analíticas e os limites de detecção (figuras 32, 33 e 34) do analito para a técnica puderam ser determinados. Para tal, uma série de soluções de MDMA em diferentes concentrações foram preparadas a partir da solução-padrão comercial da droga e submetidas à análise voltamétrica (faixa de concentração estudada: $1,0 \times 10^{-7} \mathrm{~mol} \mathrm{~L}^{-1} \mathrm{a}$ $\left.6,75 \times 10^{-4} \mathrm{~mol} \mathrm{~L}^{-1}\right)$.

O intervalo de trabalho das curvas analíticas é dado pela faixa de valores na qual a relação entre a intensidade dos picos e a concentração do analito apresenta linearidade. Os limites de detecção são os menores valores de concentração possíveis detectados. Os intervalos de trabalhos e os limites de detecção obtidos para as diferentes modalidades voltamétricas se encontram na tabela abaixo (tabela 3). 0 limite de detecção (LD) e o limite de quantificação (LQ) são obtidos através das fórmulas apresentadas abaixo ${ }^{[28]}$ :

$$
L D=\frac{3 S D}{m} \quad L Q=\frac{10 S D}{m}
$$

Equação 2 - Fórmulas para o cálculo dos limites de detecção (LD) e quantificação (LQ), onde SD é o desvio padrão e $m$ a inclinação da curva de calibração.

Os menores picos observados foram obtidos sem o uso da etapa de préconcentração, a qual não foi capaz de detectar o analito em concentrações mais baixas que as observadas, servindo apenas para intensificar o sinal quando detectado. 
Tabela 3 - Intervalos de trabalho e limites de detecção das diferentes modalidades voltamétricas estudadas.

\begin{tabular}{|c|c|c|c|}
\hline & Voltametria cíclica & $\begin{array}{l}\text { Voltametria de } \\
\text { onda quadrada }\end{array}$ & $\begin{array}{l}\text { Voltametria de } \\
\text { pulso diferencial }\end{array}$ \\
\hline $\begin{array}{l}\text { Intervalo de trabalho } \\
\qquad\left(\mathrm{mol} \mathrm{L}^{-1}\right)\end{array}$ & $\begin{array}{c}1,7.10^{-5} \\
a \\
6,75 \cdot 10^{-4}\end{array}$ & $\begin{array}{c}1,70.10^{-5} \\
a \\
6,75 \cdot 10^{-4}\end{array}$ & $\begin{array}{c}1,70.10^{-5} \\
a \\
6,75 \cdot 10^{-4}\end{array}$ \\
\hline $\begin{array}{c}\text { Quadrado do } \\
\text { coeficiente de } \\
\text { correlação linear, } \mathbf{R}^{\mathbf{2}}\end{array}$ & 0,99833 & 0,99935 & 0,99882 \\
\hline $\begin{array}{l}\text { Desvio padrão da } \\
\text { curva, SD }\end{array}$ & $8,31143 \cdot 10^{-7}$ & $6,31649 \cdot 10^{-7}$ & $1,73772.10^{-7}$ \\
\hline $\begin{array}{l}\text { Inclinação da curva } \\
\text { de calibração, m }\end{array}$ & 0,11066 & 0,13498 & 0,02755 \\
\hline $\begin{array}{l}\text { Limite de detecção, } \\
\qquad \text { LD (mol L L })\end{array}$ & $2,25.10^{-5}$ & $1,40.10^{-5}$ & $1,90.10^{-5}$ \\
\hline $\begin{array}{c}\text { Limite de } \\
\text { Quantificação, LQ } \\
\left(\mathrm{mol} \mathrm{L}^{-1}\right)\end{array}$ & $7,50.10^{-5}$ & $4,70.10^{-5}$ & $6,30 \cdot 10^{-5}$ \\
\hline
\end{tabular}



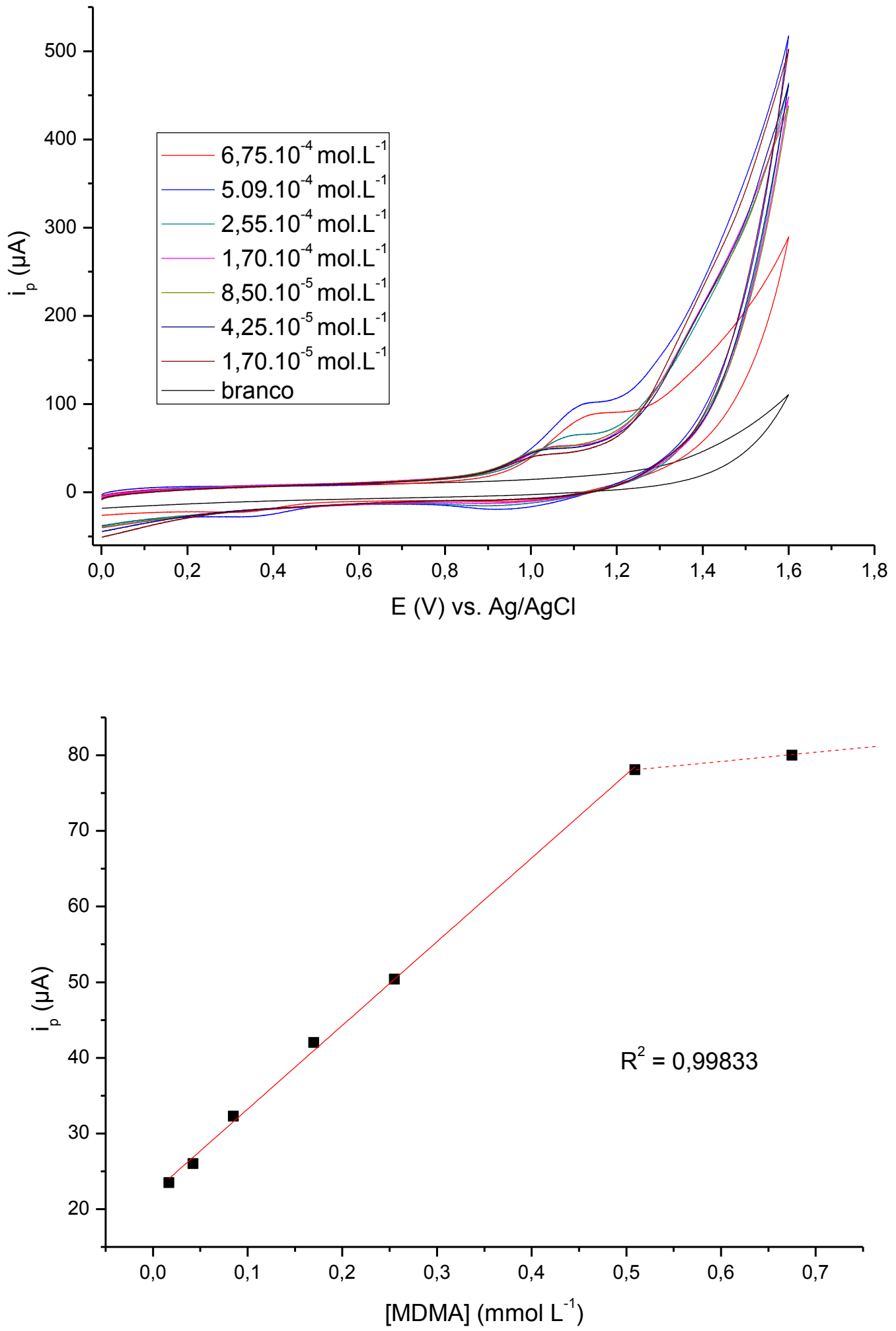

Figura 32 - Voltamogramas e gráfico de correntes de pico versus concentrações do estudo de determinação do intervalo de trabalho e limite de deteç̧ão em voltametria cíclica. 

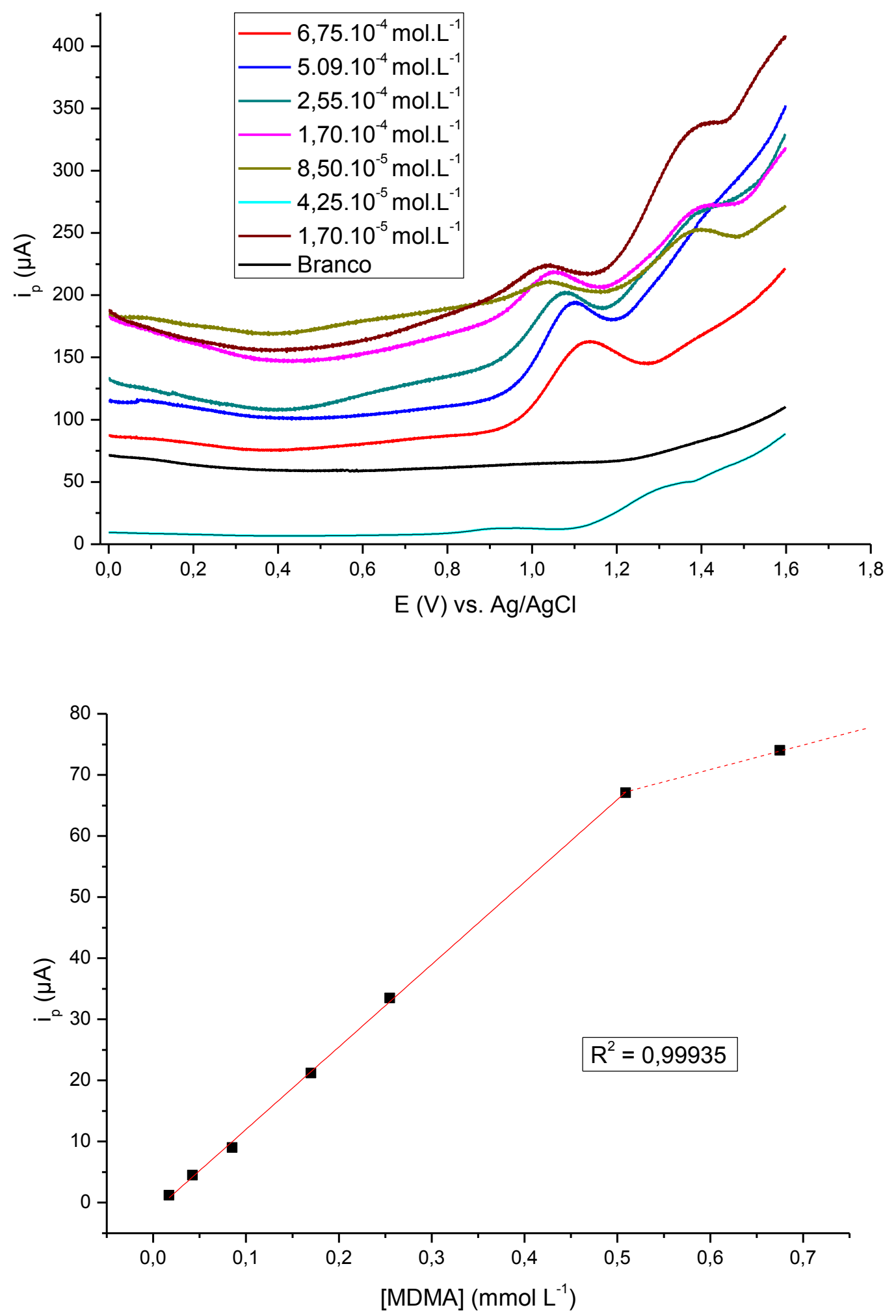

Figura 33 - Voltamogramas e gráfico de correntes de pico versus concentrações do estudo de determinação do intervalo de trabalho e limite de deteç̧ão em voltametria de onda quadrada. 

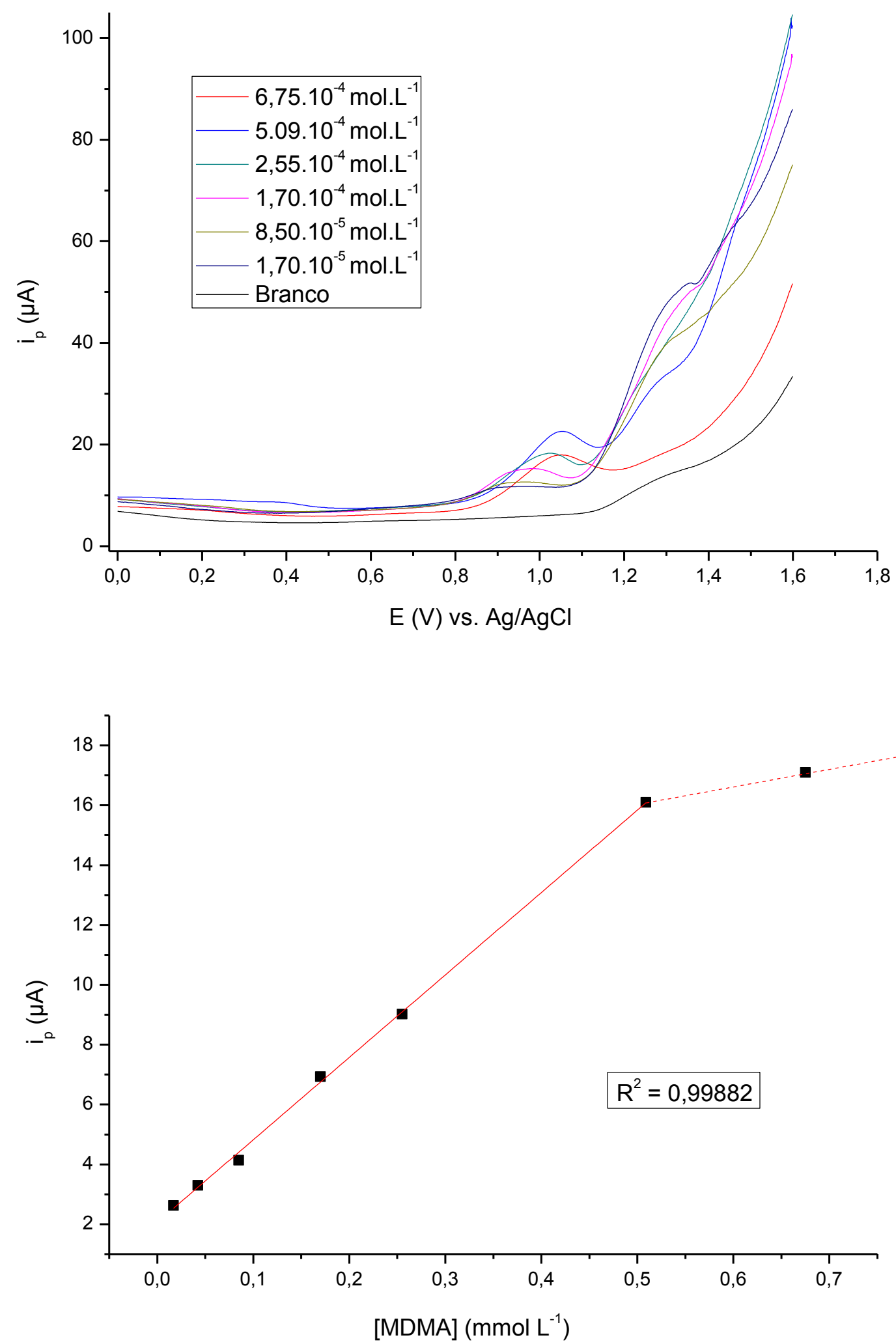

Figura 34 - Voltamogramas e gráfico de correntes de pico versus concentrações do estudo de determinação do intervalo de trabalho e limite de detecção em voltametria de pulso diferencial. 


\section{IV.4 - Determinação do teor de MDMA nos comprimidos de ecstasy}

Para a determinação do teor de MDMA em diferentes comprimidos de ecstasy, procedeu-se inicialmente com a análise espectrométrica de massas das amostras para observar as substâncias presentes nas mesmas (figura 35).

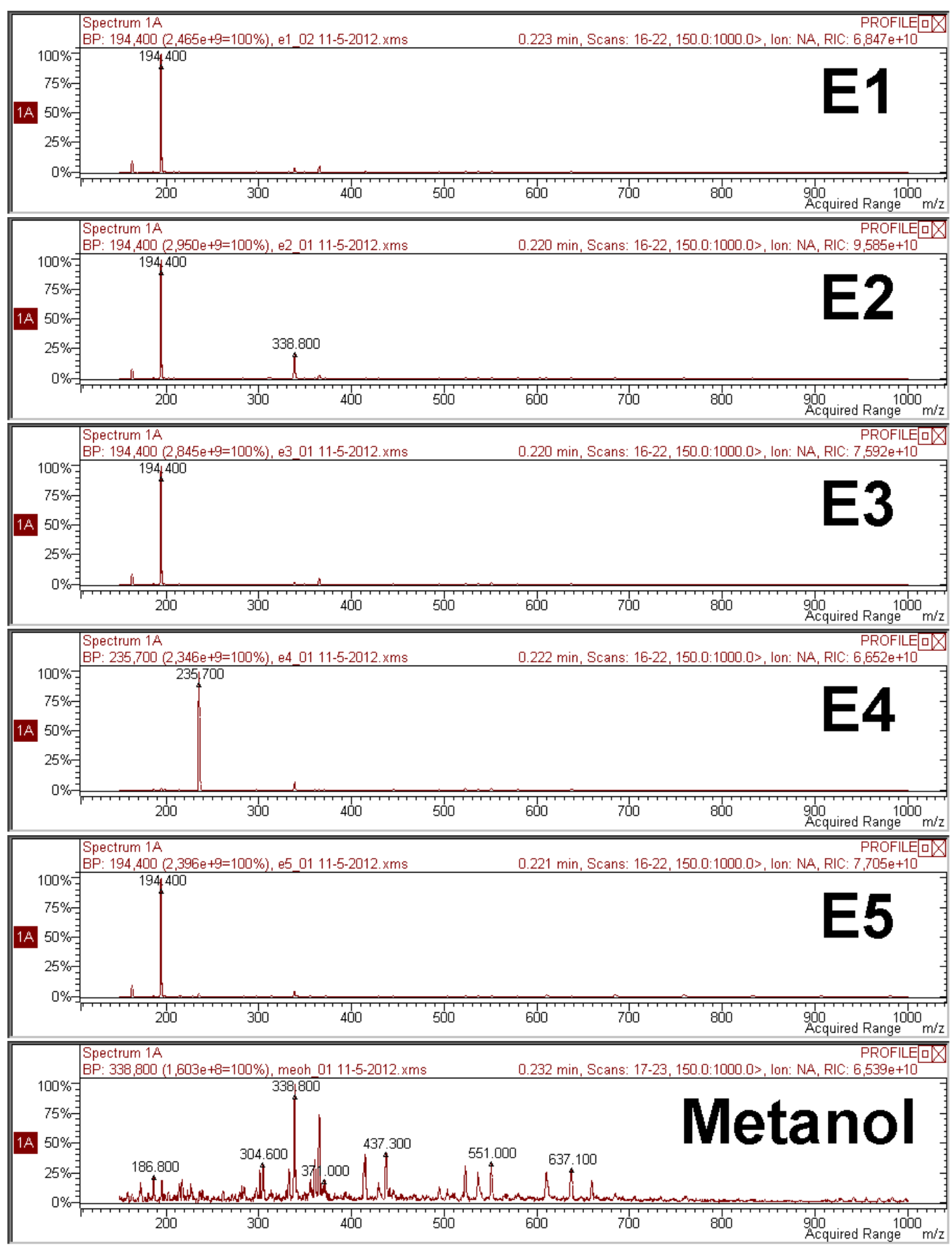

Figura 35 - Espectros de massas das cinco amostras de ecstasy analisadas e do solvente utilizado (metanol). 
Entre as cinco amostras submetidas à espectrometria de massas, apenas a amostra E4 não apresentou a presença de MDMA, ao passo que as outras quatro apresentaram somente o sinal referente à MDMA (os sinais menores são impurezas presentes no equipamento, como pode ser observado no espectro do solvente metanol, na figura 24). A amostra E4 foi ainda submetida à fragmentação por espectrometria de massas sequencial (MS/MS) para determinar a qual substância 0 pico em 235.700 se refere (figura 35). Os picos obtidos na fragmentação foram pesquisados em um banco de dados de espectros disponível na internet (www.massbank.jp) e foi obtida uma compatibilidade de 91,39\% com a substância lidocaína (figura 36), um adulterante que pode ser encontrado em comprimidos de ecstasy.

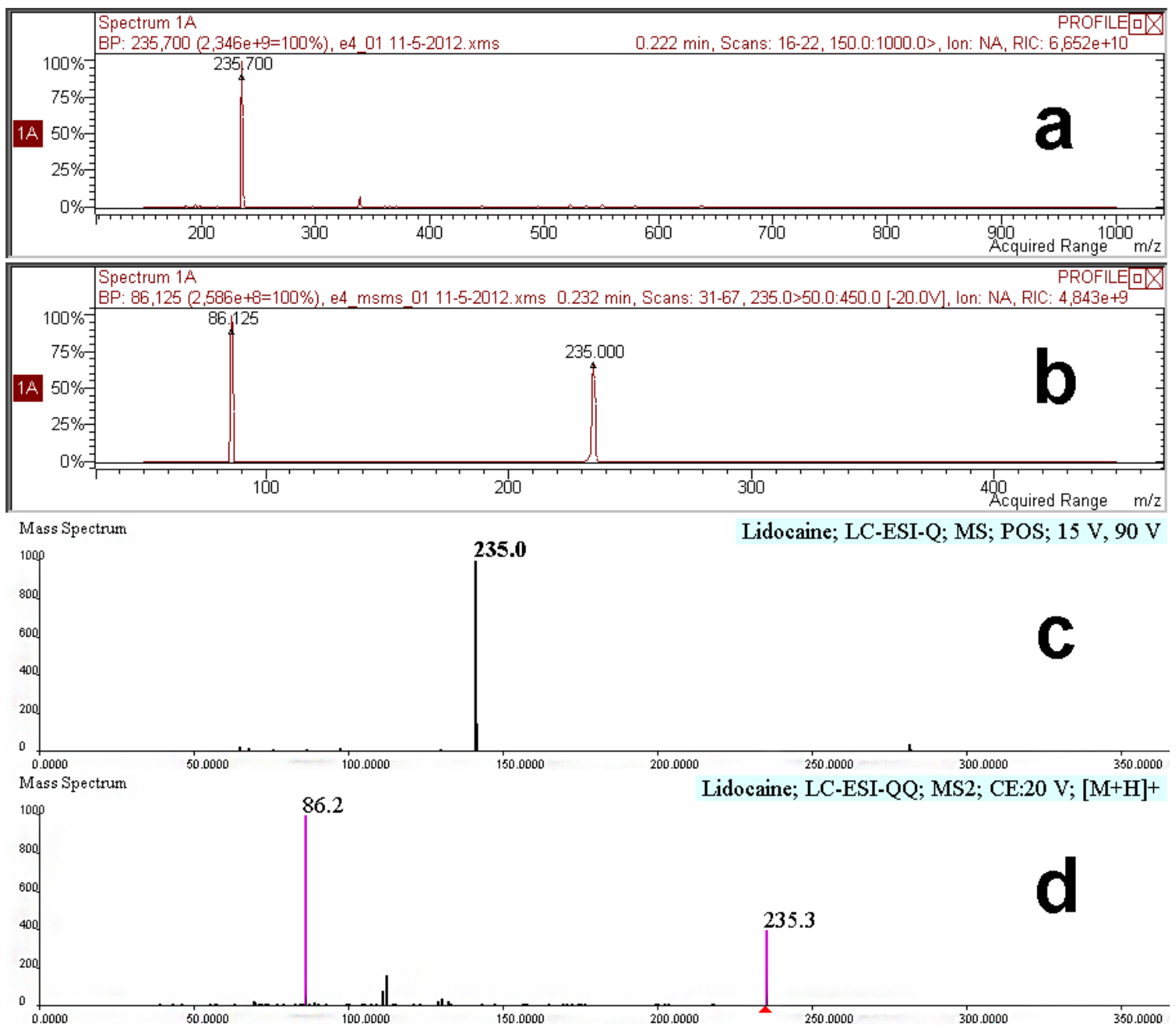

Figura 36 - a) Espectro de massas da amostra E4; b) Perfil de fragmentação da amostra E4 sob voltagem $20 \mathrm{~V}$; c) Espectro de fragmentação da lidocaína; d) Perfil de fragmentação da lidocaína sob voltagem $20 \mathrm{~V}$. 
Devido à ausência de contaminantes nas amostras que apresentaram MDMA, as mesmas foram utilizadas diretamente no sistema voltamétrico sem serem submetidas à CLAE, passando apenas pela etapa de centrifugação e separação do sobrenadante. Pelos voltamogramas (figura 37) e pelas curvas analíticas (figuras 32, 33 e 34), foi possível determinar o teor de MDMA nas amostras de ecstasy (tabela 4).

Tabela 4 - Teor de MDMA das amostras de ecstasy.

$\begin{array}{cccc}\text { Voltametria } & \text { Voltametria de } & \text { Voltametria de } & \text { Média } \\ \text { Cíclica } & \text { onda quadrada } & \text { pulso diferencial } & \text { Me }\end{array}$

(\%)

(\%)

(\%)

(\%)

\begin{tabular}{lcccc}
\hline E1 & $6,81 \pm 0,01$ & $6,14 \pm 0,03$ & $7,15 \pm 0,01$ & $6,7 \pm 0,5$ \\
E2 & $6,51 \pm 0,02$ & $6,20 \pm 0,01$ & $6,79 \pm 0,02$ & $6,5 \pm 0,3$ \\
E3 & $9,11 \pm 0,01$ & $9,96 \pm 0,04$ & $10,26 \pm 0,01$ & $9,8 \pm 0,6$ \\
E4 & --- & --- & --- & --- \\
E5 & $2,90 \pm 0,03$ & $2,85 \pm 0,01$ & $3,15 \pm 0,02$ & $2,9 \pm 0,2$
\end{tabular}



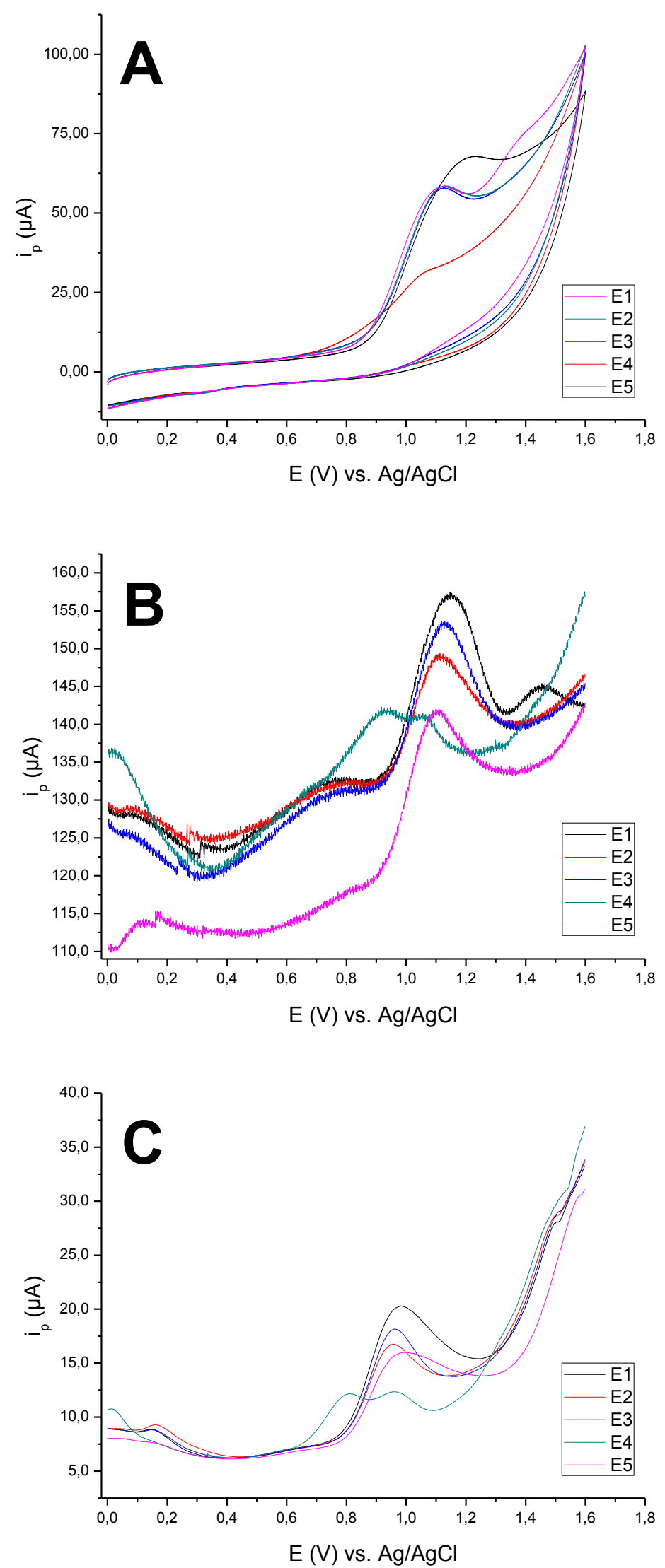

Figura 36 - Voltamogramas das amostras de ecstasy E1 a E5. a) Voltametria cíclica; b) Voltametria de onda quadrada e c) Voltametria de pulso diferencial. 


\section{V - CONCLUSÕES}

A metodologia proposta mostrou-se eficiente para a análise da 3,4metilenodioximetanfetamina nas três modalidades voltamétricas estudadas, cíclica, onda quadrada e pulso diferencial. $O$ pico voltamétrico observado em $E_{p}=+1,1 \mathrm{~V}$ caracteriza a presença da MDMA na solução e pode ser correlacionado com a concentração da mesma. Nos experimentos com alta velocidade de varredura e/ou baixa concentração do analito, um segundo pico pôde ser observado em $E_{p}=+1,4 \mathrm{~V}$.

Com a otimização dos parâmetros voltamétricos, são obtidos resultados mais confiáveis em menor tempo de análise. Construindo-se curvas analíticas, a faixa de trabalho e os limites de detecção do método puderam ser determinados e foi possível encontrar o teor de MDMA nas amostras de ecstasy. A etapa de pré-concentração intensifica o sinal voltamétrico, mas não torna a análise mais sensível, não sendo capaz de detectar concentrações menores do analito em relação à análise sem esta etapa.

Diferentemente de outros trabalhos encontrados na literatura, durante as análises voltamétricas desenvolvidas neste trabalho não houve utilização de solventes orgânicos, os quais foram substituídos por água, eliminando a utilização destes solventes que são danosos ao meio ambiente e necessitam de descarte apropriado. 


\section{VI - REFERÊNCIAS}

[1] - United Nations Office on Drug and Crime, World Drug Report, United Nations Publications, New York, 2012.

[2] - $\quad$ http://www.dpf.gov.br, acessada em março de 2012.

[3] - GREeN, A.R.; MECHAN, A.O.; ElLIOT, J.M.; O’SHEA, E.; COLADO, M.I. The pharmacology and clinical pharmacology of 3,4-methylenedioxymethamphetamine (MDMA, “Ecstasy”). Pharmacological Reviews, Baltimore, v.55, n.3, p.463-508, 2003.

[4] - Ferigolo, M.; MedeiROS, F. B.; BARROS, H. M. T.; Rev. Saúde Pública, v.32, p.487, 1998.

[5] - SIEGEL, R. K. MDMA nonmedical use and intoxication. Journal of Psychoactive Drugs., San Francisco, v.18, p.349-354, 1986.

[6] - WOLFF, K., HAY, A., SHERLOCK, K., CONNER, M. Contents of "ecstasy". Lancet, London, v.346, p.1100-1101, 1995.

[7] - KALANT, H. The pharmacology and toxicology of "ecstasy" (MDMA) and related drugs. Canadian Medical Association Journal, Ottawa, v.165, n.7, p.917-928, 2001.

[8] - PHAM, J. V.; PUZANTIAN, T. Pharmacoterapy, v.21, p.1561-1565, 2001.

[9] - $\quad$ http://thedea.org/drughistory.html, acessado em setembro de 2012.

[10] - LORENZO-FERNÁNDEZ, P.; BOBES-GARCÍA, J.; COLADO-MEGÍA, M.I. Drogas de diseño (I): MDMA (éxtasis). In: LORENZO, P; LADERO, J.M.; LEZA, J.C.; LIZASOAIN, I. Drogodependencias: farmacología, patología, psicología e legislación. Madrid: Medica Panamericana, p.157-170, 1998.

[11] - ANDERSON, G, M., BRAUN, G., BRAUN, U., NICHOLS, D. E. \& SHULGIN, A. T. Absolute configuration and psychotomirnetic phenylalkylamines, NIDA Research Monograph, 22, Rockville, NAI), 1978. 
[12] - SNYDER, S. H., FAILLACE, L. \& HOLLISTER, L. 2,5-Dimethoxy-4methylamphetamine (STP): a new hallucinogenic drug, Science, 158, p.669- 670, 1967.

[13] - NICHOLS, D. E. (1986) Differences between the rnechanism of action of MDMA, MBD13, and the classic hallucinogens. Identification of a new therapeutic class: Entactogens. Journal of Psychoactive Drugs, v.18, p.305-313, 1986.

[14] - http://www.ecstasydata.org/, acessado em setembro de 2012.

[15] - ELK, C. MDMA (Ecstasy): useful information for health professionals involved in drug education programs. Journal of Drug Education, Farmingdale, v.26, n.4, p.349356, 1996.

[16] - SHULGIN, A.T.; SARGENT, T.; NARANJO, C. The chemistry and psychopharmacology of nutmeg and several related phenylisopropylamines. In: EFRON, D., ed. Ethnological search for psychoactive drugs. Washington: US Goverment Printing Office, p.202-214. 1967.

[17] - FERIGOLO, M.; MEDEIROS, F.B.; BARROS, H.M.T. Extase: revisão farmacológica. Rev. Saúde Pública, São Paulo, v.32, n.5, p.487-495, 1998.

[18] - SCHWARTZ, R. H.; MILLER, N. S. Pediatrics, v. 100, p.705-708, 1997.

[19] - MORGAN, M. J. Psychopharmacology, p.230-248, 2000.

[20] - GOWING, L. R.; HENRY-EDWARDS, S. M.; IRVINE, R. J.; ALI, R. L. Drug And Alcohol Review, 21, p.53-63, 2002.

[21] - GREER, G.; TOLBERT, R. The Therapeutic Use of MDMA in Ecstasy: The Clinical, Pharmacological, and Neurotoxicological Effects of the Drug MDMA. ed Peroutka, SJ Boston, p.21-36, 1990.

[22] - DOBLIN R. A Clinical Plan for MDMA (Ecstasy) in the Treatment of PostTraumatic Stress Disorder (PTSD): Partnering with the FDA. Journal of Psychoactive Drugs. v. 34, p.185-194, 2002. 
[23] - SESSA, B.; NUTT, D. J. "MDMA, Politics and Medical Research: Have We Thrown the Baby Out With the Bathwater?". Journal of Psychopharmacology, Oxford, v. 21, p.787-791, 2007.

[24] - GREER, G.; TOLBERT, R. Subjective Reports of the Effects of MDMA in a Clinical Setting. Journal of Psychoactive Drugs, v. 18, p.319-327, 1986.

[25] - GREER, G.; TOLBERT, R. (1998). A Method of Conducting Therapeutic Sessions with MDMA. Journal of Psychoactive Drugs, p.30 p.371-379, 1998.

[26] - www.maps.org/mdma, acessado em agosto de 2010.

[27] - SKOOG, D. A.; WEST, D. M.; HOLLER, F. J.; CROUCH, S. R. Fundamentos de Química Analítica, Tradução da 8a Edição norte-americana, p.626-666, 2006.

[28] - HARRIS, D. C. Quantitative Chemical Analysis, 8th edition, p.376, 2011.

[29] - KOUNAVES, S.P. "Voltammetric Techniques", Handbook of Instrumental Techniques for Analytical Chemistry, F.A.Settle (Ed.) Prentice Hall PTR, Upper Saddle River, NJ, 1997.

[30] - BARD, A. J.; FAULKNER, L. R. Electrochemical methods. Fundamentals and applications, 2nd ed., p.226-260, 2001.

[31] - SKOOG, D. A.; WEST, D. M.; HOLLER, F. J.; CROUCH, S. R. Fundamentos de Química Analítica, Tradução da 8a Edição norte-americana, p.924-945, 2006.

[32] - HOFFMAN, E; STROOBANT, V. Mass Spectrometry: Principles and Applications. Chichester: John Wiley \& Sons Chichester, UK. Third Edition. 2007.

[33] - HIDVÉGI, E.; FÁBIÁN, P.; HIDEG, Z.; SOMOGYI, G. GC-MS determination of amphetamines in serum using on-line trifluoroacetylation. Forensic Science International, v. 161(2-3) p.119-123, 2006.

[34] - SAITO, T.; MASE, H.; TAKEICHI, S.; INOKUCHI, S. Rapid simultaneous determination of ephedrines, amphetamines, cocaine, cocaine metabolites, and 
opiates in human urine by GC-MS. Journal of Pharmaceutical and Biomedical Analysis, v. 43(1) p.358-363, 2007.

[35] - JIMÉNEZ, C.; DE LA TORRE, R.; VENTURA, M.; SEGURA, J.; VENTURA, R. Stability studies of amphetamine and ephedrine derivatives in urine. Journal of Chromatography B Analytical Technology in the Biomedical and Life Sciences. v.843(1), p.84-93, 2006.

[36] - CORDERO, R.; PATERSON, S. Simultaneous quantification of opiates, amphetamines, cocaine and metabolites and diazepam and metabolite in a single hair sample using GC-MS. Journal of Chromatography B Analytical Technology in the Biomedical and Life Sciences. v.850(1-2), p.423-431, 2006.

[37] - PUJADAS, M.; PICHINI, S.; POUDEVIDA, S.; MENOYO, E.; ZUCCARO, P.; FARRÉ, M.; DE LA TORRE, R. Development and validation of a gas chromatography-mass spectrometry assay for hair analysis of amphetamine, methamphetamine and methylenedioxy derivatives. Journal of Chromatography B Analytical Technology in the Biomedical and Life Sciences. v. 798(2), p.249-255, 2003.

[38] - PUJADAS, M.; PICHINI, S.; CIVIT, E.; SANTAMARIÑA, E.; PEREZ, K.; DE LA TORRE, R. A simple and reliable procedure for the determination of psychoactive drugs in oral fluid by gas chromatography-mass spectrometry. Journal of Pharmaceutical and Biomedical Analysis. V.44(2) p.594-601, 2007.

[39] - SCHEIDWEILER K. B.; HUESTIS, M. A. A validated gas chromatographic-electron impact ionization mass spectrometric method for methylenedioxymethamphetamine (MDMA), methamphetamine and metabolites in oral fluid. Journal of Chromatography B Analytical Technology in the Biomedical and Life Sciences. v. 835(1-2), p.90-99, 2006.

[40] - DE MARTINIS, B. S.; BARNES, A. J.; SCHEIDWEILER, K. B.; HUESTIS, M. A. Development and validation of a disk solid phase extraction and gas chromatographymass spectrometry method for MDMA, MDA, HMMA, HMA, MDEA, methamphetamine and amphetamine in sweat Journal of Chromatography $B$ 
Analytical Technology in the Biomedical and Life Sciences, v. 852(1-2), p. 450-458, 2007.

[41] - VLASE, L.; POPA, D.S.; LOGHIN, F.; LEUCUTA, S. E. High-throughput toxicological analysis of Methamphetamine, MDA and MDMA a by LC-MS/MS. Romanian Journal of Legal Medicine Vol. XVII, nr. 3, p. 213-220, 2009.

[42] - GARRIDO, E.M.P.J.; GARRIDO, J.M.P.J.; MILHAZES, N.; BORGES, F.; OLIVEIRABRETT, A.M. Electrochemical oxidation of amphetamine-like drugs and application to electroanalysis of ecstasy in human serum. Bioelectrochemistry v.79, p.77-83, 2010.

[43] - CARDOSO, J.L. Desenvolvimento de sistemas portáteis de monitoramento eletroquímico. São Paulo, Dissertação de mestrado. Escola Politécnica, USP, p.146, 2007.

[44] - JANATA, J. Principles of chemical sensors. Plenum, New York, E.U.A., p.317, 1989.

[45] - STRADIOTTO, N R; YAMANAKA, H; ZANONI, M V B. Electrochemical Sensors: A powerful tool in analytical chemistry. Journal of Brazilian Chemical Society. v.14, p.159-173, 2003.

[46] - ROVER, L.; NETO, G.D.; KUBOTA, L.T. Transdutores Potenciométricos à base de polímeros condutores: Aplicações Analíticas. Química Nova, v.20, p. 519-523, 1997.

[47] - BAIZER, M. Organic Electrochemistry; 2 Ed., Marcel Decker, Inc., New York, E.U.A., p. 464-465, 1972.

[48] - KUSLEZA, P.J.; COX, J.A. Solid state voltammetry. Analytical Prospects Eletroanalysis, v.10, p. 73-80, 1998. 